\title{
Energy performance analysis of a novel solar PVT loop heat pipe employing a microchannel heat pipe evaporator and a PCM triple heat exchanger
}

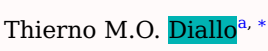

Abstract

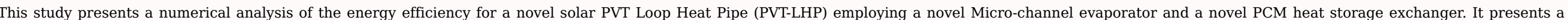

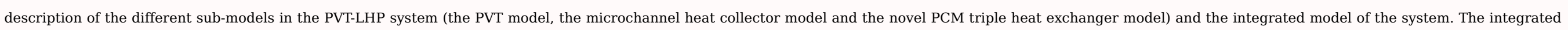

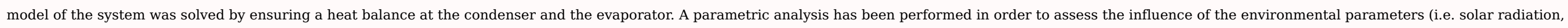

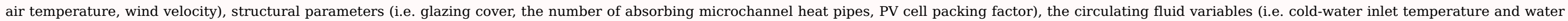

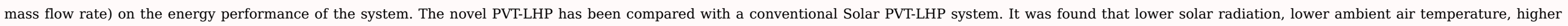

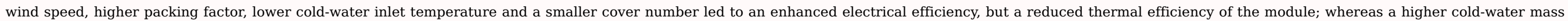

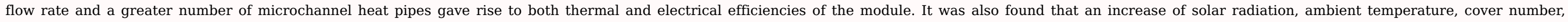

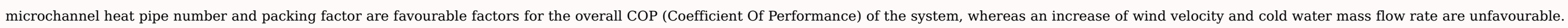

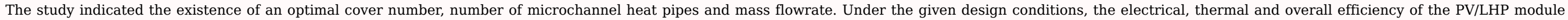

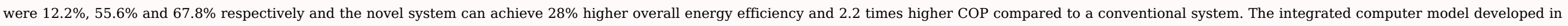
this study can be used to design and optimize the novel PVT-LHP heating system.

Keywords: PVT; Loop heat pipe; Microchannel; PCM triple heat exchanger; Heating; Power supply

\section{Nomenclature}

area $\left[\mathrm{m}^{2}\right]$ 
mini-channel widt

mini-channel height [m]

Bo

Bond number [m]

C

heat capacity [W/K]

C, d

discharge coefficient [-]

$\mathrm{D}, \mathrm{d}$

diameter $[\mathrm{m}]$

e

thickness [m]

f

liquid fraction, friction factor [-]

g

gravitational acceleration $9.81\left[\mathrm{~m} / \mathrm{s}^{2}\right]$

G

mass velocity $\left[\mathrm{kg} / \mathrm{m}^{2} / \mathrm{s}\right]$

$\mathrm{H}$

height $[\mathrm{m}]$

$\mathrm{h}$

heat transfer coefficient $\left[\mathrm{W} / \mathrm{m}^{2} / \mathrm{K}\right]$

$\mathrm{h}_{\mathrm{fg}}$

latent heat of vaporisation $[\mathrm{J} / \mathrm{kg} / \mathrm{K}]$

$\mathrm{k}$

thermal conductivity [W/m/K]

L 
variable $\left[\mathrm{m}^{-1}\right]$

number [-]

$\mathrm{N}_{\mathrm{ch}}$

number channel ports [-]

$\mathrm{Nu}$

Nusselt number [-]

pressure $[\mathrm{Pa}]$

$\Delta \mathrm{P}$

pressure drop [Pa]

q

heat density $\left[\mathrm{W} / \mathrm{m}^{2}\right]$

heat transfer rate [W]

specific gas constant [J/(kg K)]

$\mathrm{R}$

radius $[\mathrm{m}]$

thermal resistance $[\mathrm{W} / \mathrm{K}]$

Re

Reynolds number [-]

temperature $\left[{ }^{\circ} \mathrm{C} /{ }^{\circ} \mathrm{K}\right.$

heat loss $[\mathrm{W} / \mathrm{K}]$ 
velocity $[\mathrm{m} / \mathrm{s}]$

collector width [m]

vapour quality [-]

Subscripts

an

annular

av

average

c

cold, charge, cover

ch

channel

cond

condensation

d

discharge

f

fin

F

efficiency factor

e

evaporator, electrical

eq

equivalent

ei

electrical insulation 
ethylene-vinyl acetate

fluid gas

gravity

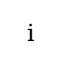

inlet

$\min$

minimum

$\mathrm{mt}$

middle tube

h

hole, header

he

heat exchanger

heat pipe

hp-he

heat pipe to heat exchanger

lf

the liquid film

lh

liquid header

LO

liquid only

ltl

liquid transportation line 
liquid

L

loss

liquid film

o

overall

out

outlet

$\mathrm{p}$

PV cell

PCM

phase change material

Pr

Pranlt

p-fin

PV-Fin

th

thermal

tp

two-phase

utile

vapour

vtl

vapour transportation line 


\section{Introduction}

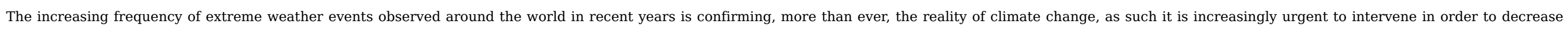

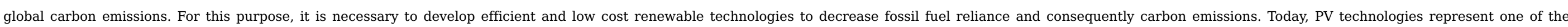

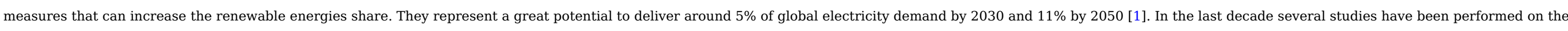

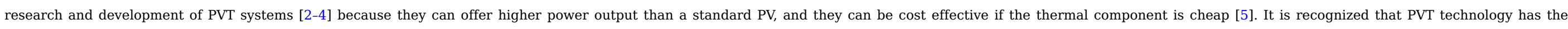

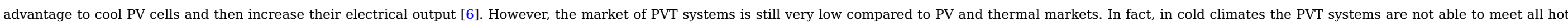

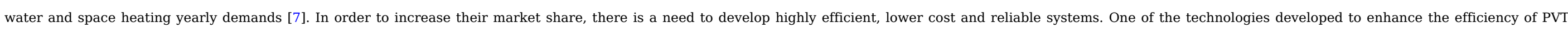

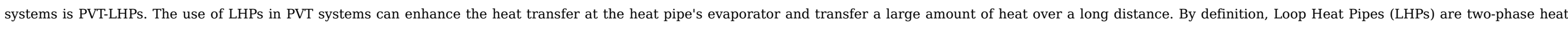

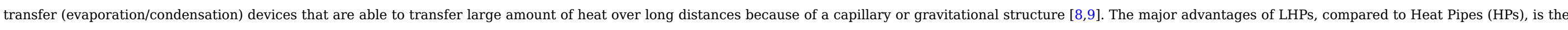

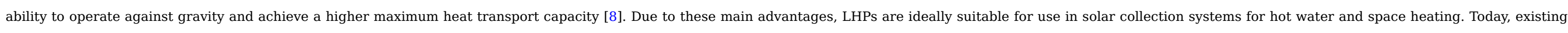

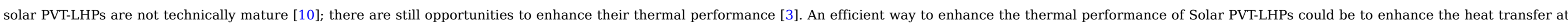




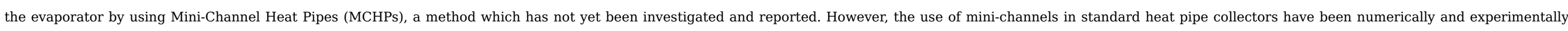

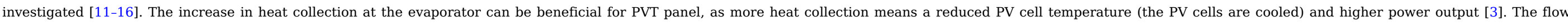

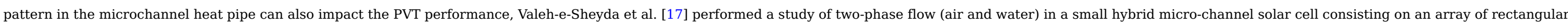

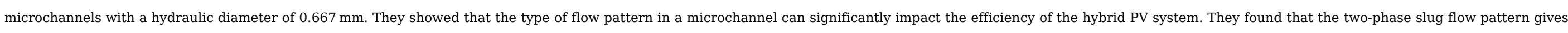

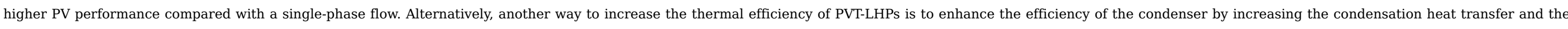

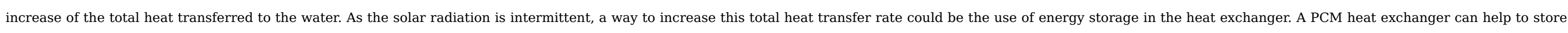

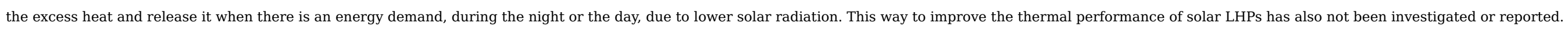

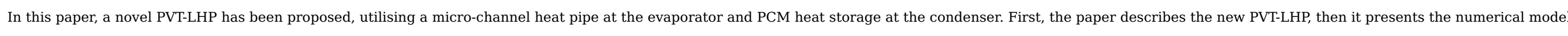

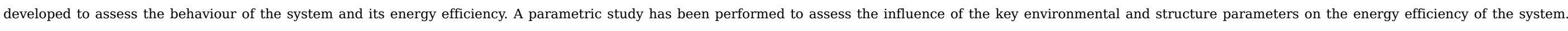

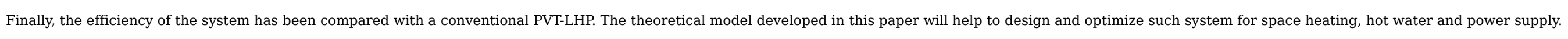

\section{Presentation of the novel solar PVT- LHP system}

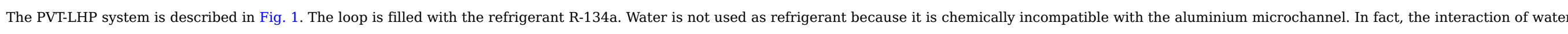

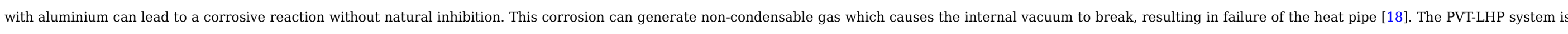

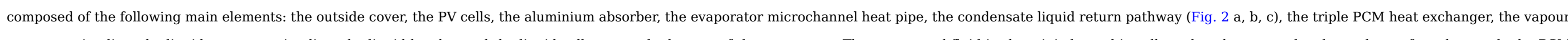

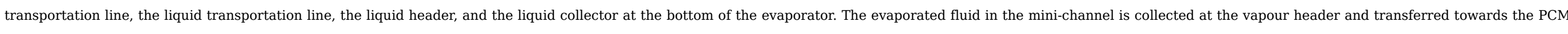

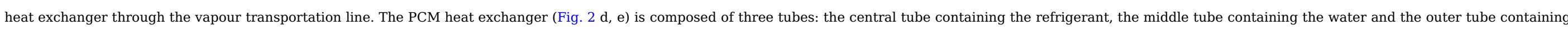

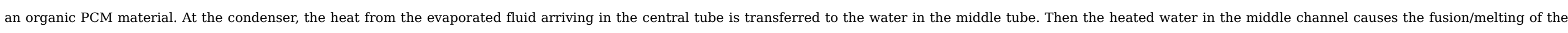

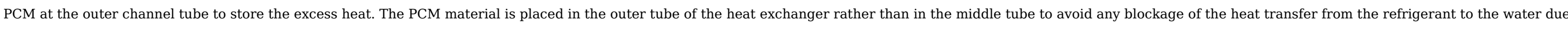

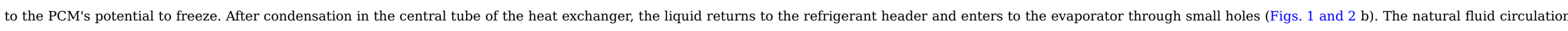

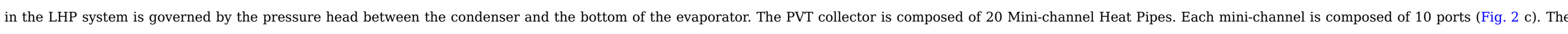

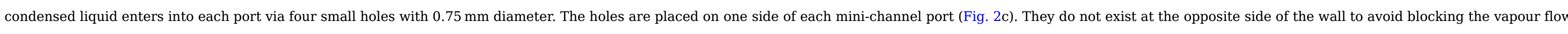

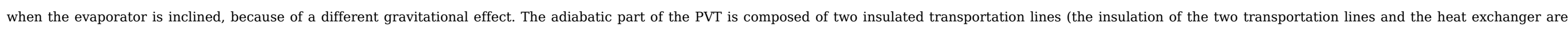
shown in Fig. 1). 


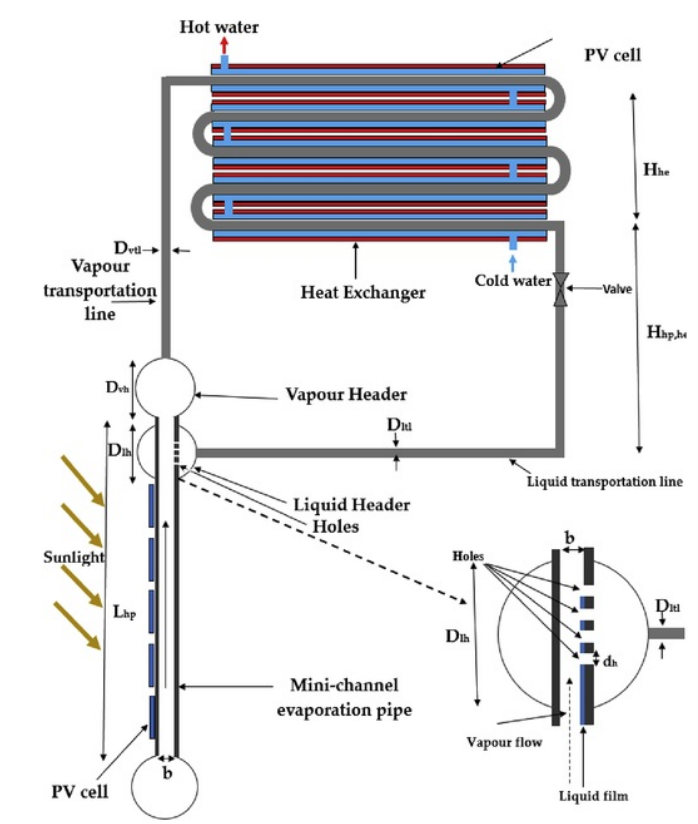

Fig. 1 Schematic of the novel Solar Loop Heat Pipe. alt-text: Fig. 1 

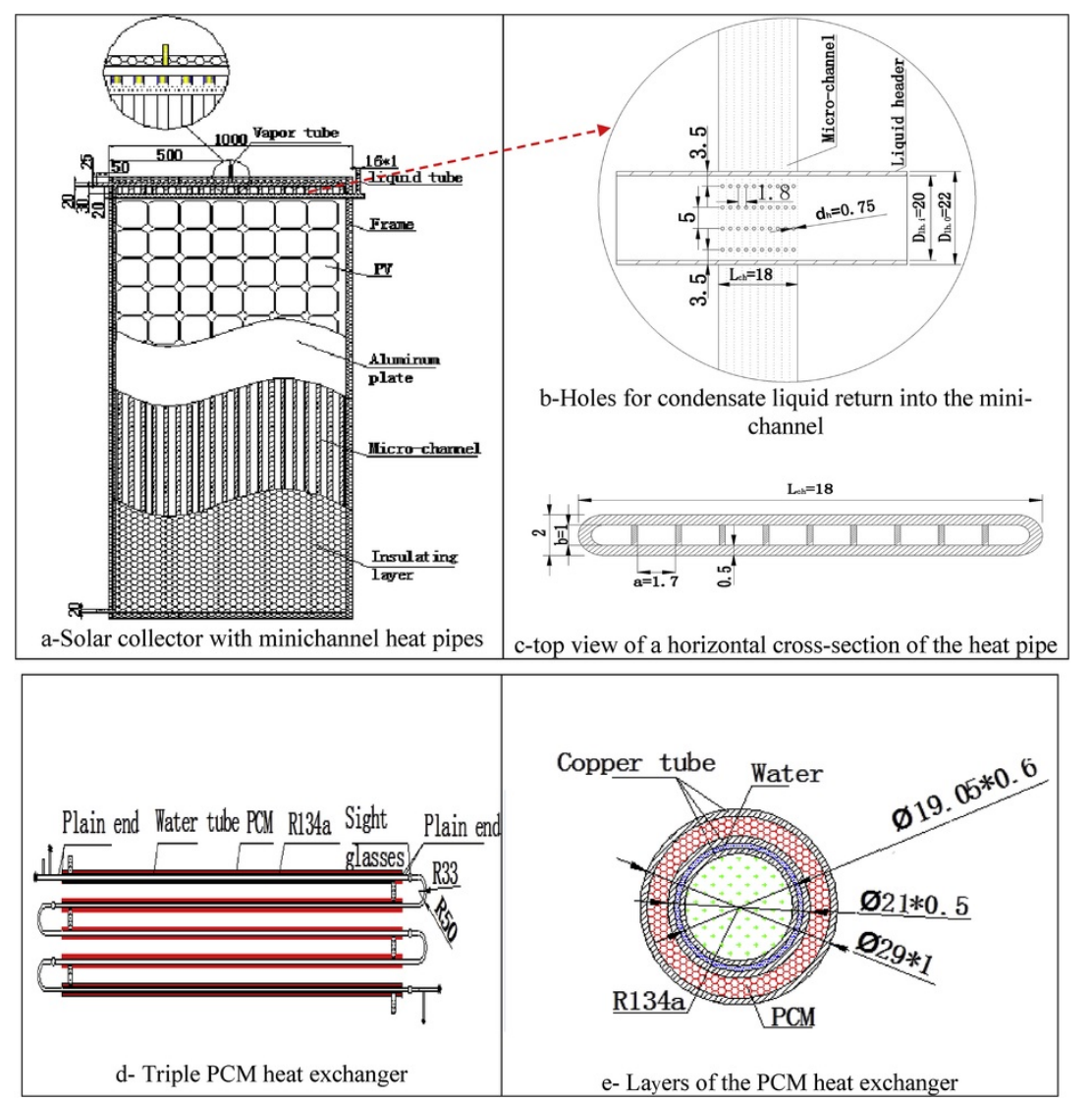

Fig. 2 Solar collector with minichannel heat pipes, condensate liquid pathway and the PCM heat exchanger (units in mm). alt-text: Fig. 2

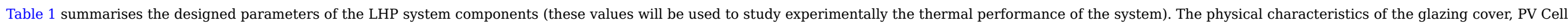
EVA and electrical insulation are presented in Annex 1.

Table 1 Design parameters of the LHP operation and heat exchanger.

alt-text: Table 1

\begin{tabular}{|c|c|c|c|}
\hline Parameters & Nomenclature & Value & Unit \\
\hline Mini-channel port width & a & 0.0017 & $\mathrm{~m}$ \\
\hline Mini-channel port height & $\mathrm{b}$ & 0.001 & $\mathrm{~m}$ \\
\hline Evaporator length & $\mathrm{L}_{\mathrm{hp}}$ & 1.9 & $\mathrm{~m}$ \\
\hline Number of mini-channel heat pipes & $\mathrm{N}_{\mathrm{hp}}$ & 20 & - \\
\hline Number of mini-channel ports & $\mathrm{N}_{\mathrm{p}}$ & 10 & - \\
\hline Total number of mini-channel ports & $\mathrm{N}_{\mathrm{ch}}$ & 200 & - \\
\hline
\end{tabular}




\begin{tabular}{|c|c|c|c|}
\hline Operating temperature range & $t_{v}$ & $20-60$ & ${ }^{\circ} \mathrm{C}$ \\
\hline Evaporator to condenser height difference & $\mathrm{H}_{\text {hp-he }}$ & 0.6 & $\mathrm{~m}$ \\
\hline Transportation line outer diameter & $\mathrm{D}_{\mathrm{ltl}, 0} / \mathrm{D}_{\mathrm{vtl}, \mathrm{o}}$ & 0.015 & $\mathrm{~m}$ \\
\hline Transportation line inner diameter & $\mathrm{D}_{\mathrm{ltt}, \mathrm{i}} / \mathrm{D}_{\mathrm{vtl}, \mathrm{i}}$ & 0.0174 & $\mathrm{~m}$ \\
\hline Liquid head length & $\mathrm{L}_{\mathrm{lh}}$ & 1 & $\mathrm{~m}$ \\
\hline Liquid Head diameter & $\mathrm{D}_{\mathrm{lh}}$ & 0.022 & $\mathrm{~m}$ \\
\hline Vapour header length & $\mathrm{L}_{\mathrm{vh}}$ & 1 & $\mathrm{~m}$ \\
\hline Hole diameter & $d_{h}$ & 0.00075 & $\mathrm{~m}$ \\
\hline Transportation line length & $\mathrm{L}_{\mathrm{lt} 1} / \mathrm{L}_{\mathrm{vtl}}$ & $1 / 1$ & $\mathrm{~m}$ \\
\hline Heat exchanger central tube total length & $\mathrm{L}_{\mathrm{he}}$ & 5 & $\mathrm{~m}$ \\
\hline Heat exchanger central tube diameters & $\mathrm{D}_{1} / \mathrm{D}_{2}$ & $0.016 / 0.017$ & $\mathrm{~m}$ \\
\hline Heat exchanger middle tube diameters & $\mathrm{D}_{2} / \mathrm{D}_{4}$ & $0.019 / 0.021$ & $\mathrm{~m}$ \\
\hline PCM tube diameters & $\mathrm{D}_{5} / \mathrm{D}_{6}$ & $0.027 / 0.029$ & $\mathrm{~m}$ \\
\hline PCM melting temperature & $\mathrm{T}_{\mathrm{pcm}}$ & 44 & ${ }^{\circ} \mathrm{C}$ \\
\hline PCM density & $\rho_{\mathrm{pcm}}$ & 800 & $\mathrm{~kg} / \mathrm{m}^{3}$ \\
\hline PCM Latent Heat & $\mathrm{L}_{\mathrm{h}}$ & 242 & $\mathrm{~kJ} / \mathrm{kg}$ \\
\hline PCM thermal conductivity & $\lambda_{\mathrm{pcm}}$ & 0.18 & $\mathrm{~W} / \mathrm{mK}$ \\
\hline PCM Maximum operating temperature & $\mathrm{T}_{\text {pcm-max }}$ & 300 & ${ }^{\circ} \mathrm{C}$ \\
\hline
\end{tabular}

\section{Mathematical model of the solar energy conversion}

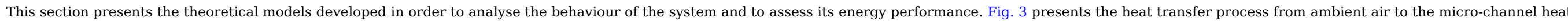
pipe evaporator. This heat transfer includes four processes (as shown in Fig. 3):

1) Absorption of part of the solar radiation and dissipation of the remaining heat into the ambient air.

2) Conversion of part of the absorbed energy into electricity through PV cells.

3) Transportation of the remaining part of the absorbed energy into the passing refrigerant in the microchannel heat pipe. The evaporated refrigerant flows towards the PCM heat exchanger.

4) Transfer of the heat from the central tube of the Triple PCM heat exchanger to the middle tube containing the water. 


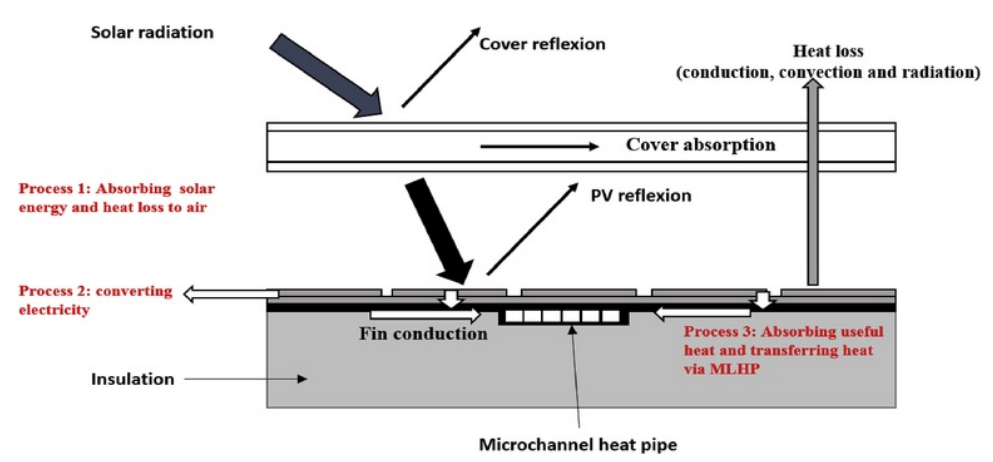

Fig. 3 Heat transfer from ambient air to the microchannel evaporator. alt-text: Fig. 3

\subsection{Model of the heat transfer from the ambient air to the microchannel evaporator}

Fig. 3 presents the heat transfer process from the outside air to the microchannel evaporator. The heat transfer model from the surrounding air to absorber plate is presented in Annex 2 [19].

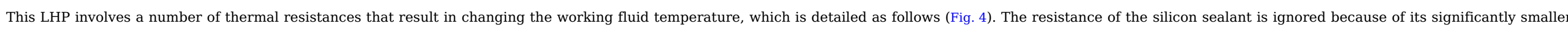
value compared to the other factors.

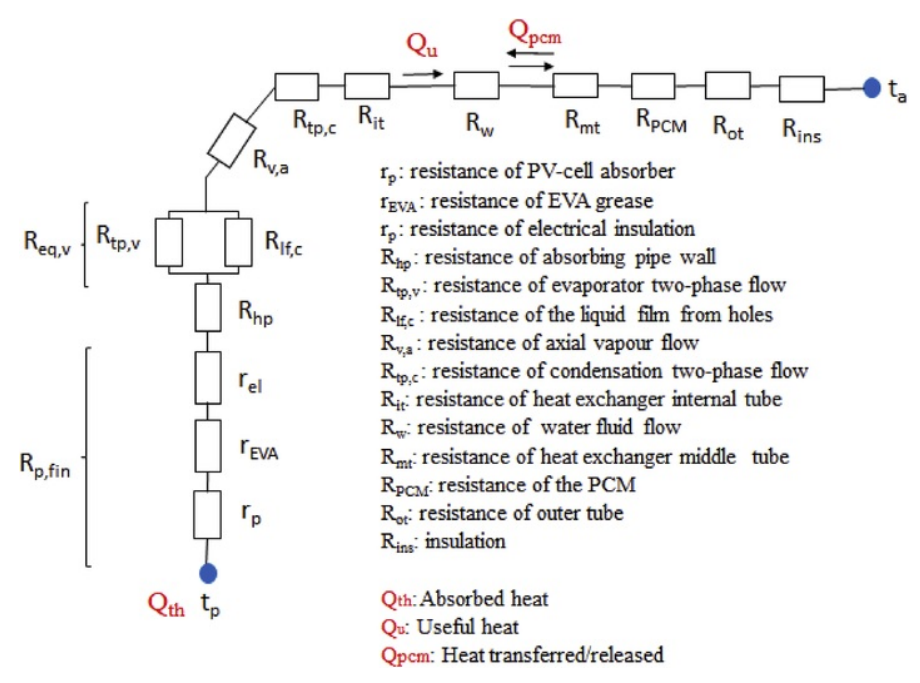

Fig. 4 Schematic of heat transfer along the PVT-LHP.

alt-text: Fig. 4

The total useful solar heat received by the water in the middle tube of the PCM triple heat exchanger is expressed through the Hottel-Whillier model [19,20] from fin to microchannel: $\mathrm{Q}_{\mathrm{u}}=\mathrm{LW} \mathrm{F}$ th $\left[\mathrm{q}_{\text {abs }}-\mathrm{U}_{\mathrm{L}}\left(\mathrm{T}_{\mathrm{c}, \mathrm{av}}-\mathrm{T}_{\mathrm{a}}\right)-\mathrm{q}_{\mathrm{e}}\right]$

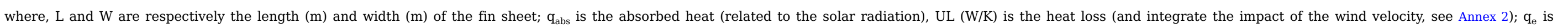

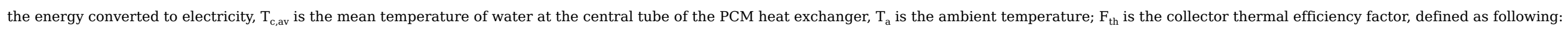




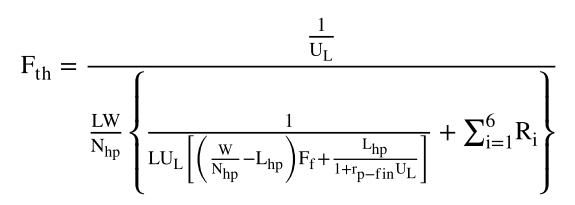

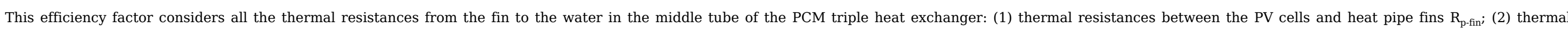

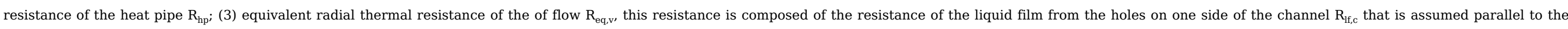

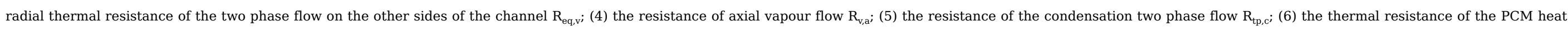
exchanger central tube $\mathrm{R}_{\mathrm{it}}$.

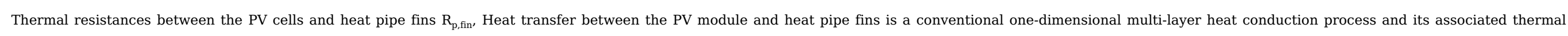
resistance is [19]:

$\mathrm{R}_{\mathrm{p}-\mathrm{fin}}=\mathrm{r}_{\mathrm{p}}+\mathrm{r}_{\mathrm{EVA}}+\mathrm{r}_{\mathrm{ei}}=\frac{\delta_{\mathrm{p}}}{\mathrm{k}_{\mathrm{p}}}+\frac{\delta_{\mathrm{EVA}}}{\mathrm{k}_{\mathrm{EVA}}}+\frac{\delta_{\mathrm{ei}}}{\mathrm{k}_{\mathrm{ei}}}$

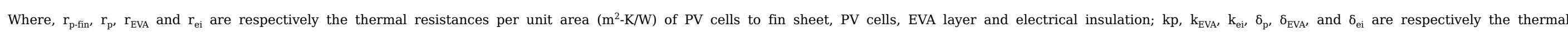

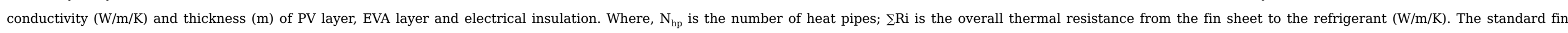
efficiency, $\mathrm{F}_{\mathrm{f}}$, is defined as:

$\mathrm{F}_{\mathrm{f}}=\frac{\tanh \left[\mathrm{m}\left(\mathrm{W} / \mathrm{N}_{\mathrm{hp}}-\mathrm{L}_{\mathrm{hp}}\right) / 2\right]}{\mathrm{m}\left(\mathrm{W} / \mathrm{N}_{\mathrm{hp}}-\mathrm{L}_{\mathrm{hp}}\right) / 2}$

Where the variable $\mathrm{m}$, is given by:

$m=\sqrt{\frac{U_{L}}{k_{f} \delta_{f}\left(1+r_{p-f i n} U_{L}\right)}}$

Thermal resistance of heat pipe wall, $\mathrm{R}_{\mathrm{hp}}$, Heat transfer through the heat pipe wall is a typical steady-state conduction process, and its thermal resistance can be written as:

$\mathrm{R}_{\mathrm{hp}}=\frac{\mathrm{e}_{\mathrm{hp}}}{\mathrm{k}_{\mathrm{hp}}\left(2 \times(\mathrm{a}+\mathrm{b}) \times \mathrm{L}_{\mathrm{hp}}\right) \mathrm{N}_{\mathrm{hp}}}$

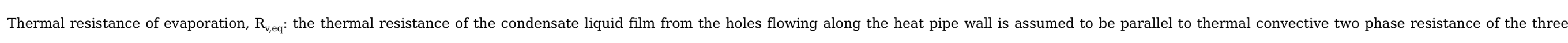
other sides of the channel port. The equivalent thermal resistance is expressed as follows:

$\mathrm{R}_{\mathrm{eq}, \mathrm{v}}=\left(\frac{1}{\mathrm{R}_{\mathrm{tp}, \mathrm{v}}}+\frac{1}{\mathrm{R}_{\mathrm{ff}, \mathrm{v}}}\right)^{-1}$

The total resistance of the condensate liquid film $R_{\mathrm{lf}, \mathrm{v}}$ of thickness $\delta_{\mathrm{lf}}$ at the adjacent sides of the micro channel holes is expressed as follows:

$$
\mathrm{R}_{\mathrm{lf}, \mathrm{v}}=\frac{\delta_{\mathrm{lf}}}{\mathrm{k}_{\mathrm{w}}\left(\mathrm{a} \times \mathrm{L}_{\mathrm{hp}}\right) \mathrm{N}_{\mathrm{hp}} \mathrm{N}_{\mathrm{ch}}}
$$

The resistance of the two-phase flow is expressed as follows:

$$
\mathrm{R}_{\mathrm{tp}, \mathrm{v}}=\frac{1}{(\mathrm{a}+2 \mathrm{~b}) \varepsilon_{\mathrm{of}} \mathrm{L}_{\mathrm{hp}} \mathrm{h}_{\mathrm{tp}} \mathrm{N}_{\mathrm{hp}}}
$$

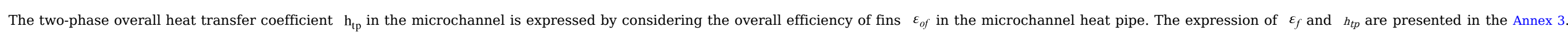

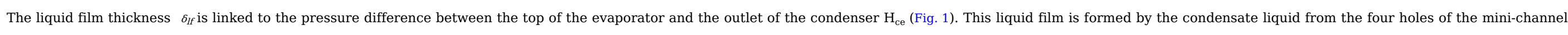




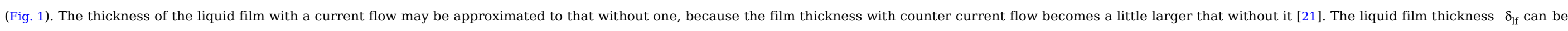
approximated as follows:

$\delta_{\text {lf }}=\left(\frac{3 \mu_{1}^{2}}{\rho_{1}^{2} g}\right)^{1 / 3} \operatorname{Re}^{1 / 3}$ for $\operatorname{Re} \leq 400$

And

$\delta_{\text {If }}=0.369\left(\frac{3 \mu_{1}^{2}}{\rho_{1}^{2} \mathrm{~g}}\right)^{1 / 2} \mathrm{Re}^{1 / 2}$ for $\mathrm{Re}>400$

With: Re the Reynolds number, $\mu_{1}$ (Pa.s) the liquid dynamic viscosity, $g\left(\mathrm{~m} / \mathrm{s}^{2}\right)$. The Reynolds number is given by:

$\operatorname{Re}=\frac{\rho_{1} U_{1} \delta_{1 f}}{\mu_{1}}$

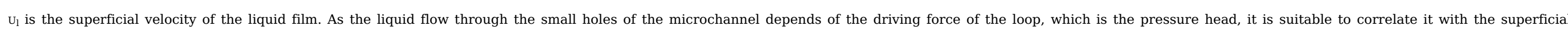
flow. Then, the superficial velocity $\mathrm{u}_{1}$ is linked to the pressure head by the following equation (it is simply expressed as a liquid flowing throughout a hole because of the pressure head):

$\mathrm{u}_{1}=\mathrm{A}_{\mathrm{h}} \frac{\left(2 \mathrm{~g} \mathrm{H}_{\mathrm{hp}-\mathrm{he}}\right)^{\frac{1}{2}}}{\mathrm{~A}_{\mathrm{l}}\left(1-\mathrm{Cd}^{2}\left(\mathrm{~d}_{\mathrm{h}} / \mathrm{D}_{\mathrm{lh}}\right)\right)}$

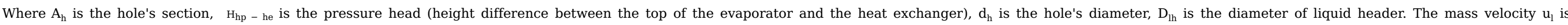
assumed the same for the four holes, then the film thickness is assumed the same along the adjacent wall. $\mathrm{A}_{1}$ is the liquid film section expressed as follows:

$\mathrm{S}_{1}=\delta_{\mathrm{lf}} \mathrm{a}$

a is the mini-channel port width. $\mathrm{Cd}[-]$ is, the discharge coefficient of the flow from the liquid head to the hole and expressed as follows [22]:

$\mathrm{C}_{\mathrm{d}}=0.611\left[87\left(\frac{\mu_{1}}{\rho_{1} \mathrm{~d}_{\mathrm{h}} \sqrt{\mathrm{g} \mathrm{H} \mathrm{hp}_{\mathrm{he}}}}\right)^{1.43}+\left(1+\frac{4.5 \mu_{1}}{\rho_{1} \mathrm{~d}_{\mathrm{h}} \sqrt{\mathrm{g} \mathrm{H} \mathrm{hp}_{\mathrm{he}}}}\right)^{-1.26}\right]^{-0.7}$

The liquid thickness $\delta_{\mathrm{If}}$ is calculated iteratively by assuming that the liquid mass flow from the liquid header is equal to the mass flow of the liquid film.

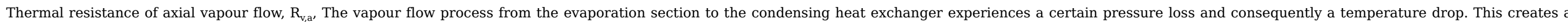
resistance in heat transfer which could be written as:

$\mathrm{R}_{\mathrm{v}, \mathrm{a}}=\frac{\mathrm{T}_{\mathrm{v}}^{2} \mathrm{R}_{0} \Delta \mathrm{P}_{\mathrm{v}} \mathrm{N}_{\mathrm{hp}} \mathrm{N}_{\mathrm{ch}}}{\mathrm{Q}_{\mathrm{u}} \mathrm{h}_{\mathrm{fg}} \mathrm{P}_{\mathrm{v}}}$

The total pressure drop of the system has been expressed as given in Ref. [23].

Thermal resistance of the condensation, $\mathrm{R}_{\text {cond }}$, Heat transfer through the heat pipe wall is a typical steady-state conduction process, and its thermal resistance can be written as:

$\mathrm{R}_{\text {cond }}=\frac{1}{2 \uparrow \pi \mathrm{d}_{1} \mathrm{~L}_{\mathrm{hx}} \mathrm{h}_{\text {cond }}}$

The condensation heat transfer coefficient $\mathrm{h}_{\text {cond }}$ is given in Annex 3.

\subsection{Mathematical model of the heat transfers in the heat triple heat exchanger}

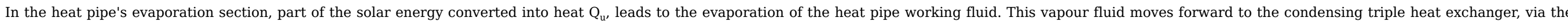

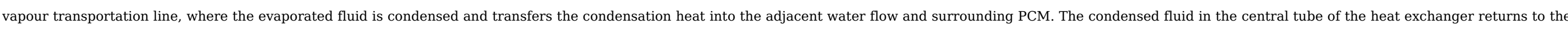




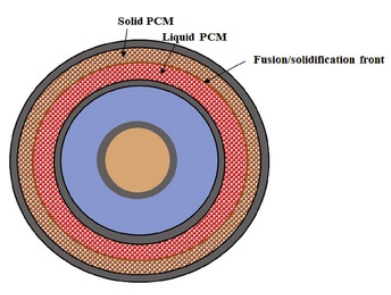

Fig. 5 Sketch map of phase change process. alt-text: Fig. 5

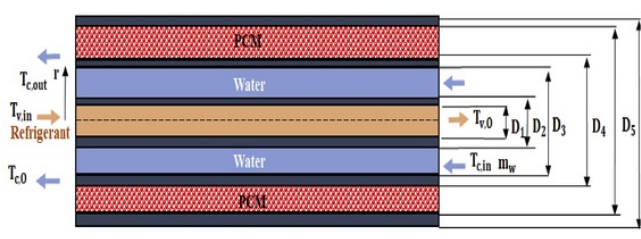

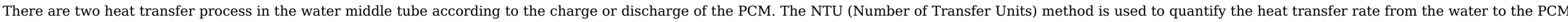
material.

\subsubsection{Charging the PCM}

The heat transferred from water in the middle tube to the PCM is expressed as following

$\mathrm{Q}_{\mathrm{c}}=\varepsilon_{\mathrm{c}} \mathrm{C}_{\min }\left(\mathrm{T}_{\mathrm{c}, \text { out }}-\mathrm{T}_{\mathrm{c}, \mathrm{in}}\right)$

With $\mathrm{C}_{\min }(\mathrm{W} / \mathrm{K})$ is the minimum heat transfer capacity, $\varepsilon_{c}$ is the average effectiveness of the melting process and is expressed as follows [24]:

$\varepsilon_{\mathrm{c}}=\int_{0}^{1}\left(1-\exp \left(-\frac{1}{\mathrm{R}_{\mathrm{T}} \mathrm{C}_{\text {min }}}\right)\right) \mathrm{d} f$

Where $\mathrm{f}$ is the fraction of melted PCM and varies from 0 (only solid) to 1 (only liquid), $\mathrm{R}_{\mathrm{T}}$ is the total resistance from the water to the PCM material and is expressed as follows:

$\mathrm{R}_{\mathrm{T}}=\mathrm{R}_{\mathrm{w}}+\mathrm{R}_{\mathrm{mt}}+\mathrm{R}_{\mathrm{PCM}}$

Where $R_{w}$ is the water resistance, $R_{m t}$ is the resistance of the middle tube and $R_{P C M}$ is the resistance of the PCM. The different resistances are expressed as follows:

$\mathrm{R}_{\mathrm{w}}=\frac{1}{\mathrm{~h}_{\mathrm{w}} \pi \mathrm{D}_{2} \mathrm{~L}_{\mathrm{he}}}$

The convective heat transfer coefficient $h_{w}$ of the water on the annulus side can be calculated by

$\mathrm{h}_{\mathrm{w}}=\frac{\mathrm{Nu} \mathrm{k}_{\mathrm{w}}}{\mathrm{D}_{45}}$

The Nusselt number $\mathrm{Nu}$ of the annulus water flow is given in Annex 4

Thermal resistance of the middle tube $\mathrm{R}_{\mathrm{m}}$, the conductive thermal resistance of the middle tube is expressed as follows:

$\mathrm{R}_{\mathrm{mt}}=\frac{1}{2 \pi \mathrm{k}_{\mathrm{mt}} \mathrm{L}_{\mathrm{he}}} \log \left(\frac{\mathrm{D}_{4}}{\mathrm{D}_{3}}\right)$

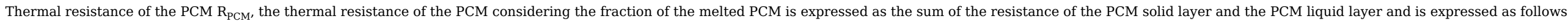

$\mathrm{R}_{\mathrm{PCM}}=\log \left(\frac{\left(\mathrm{f}\left(\mathrm{R}_{5}^{2}-\mathrm{R}_{4}^{2}\right)+\mathrm{R}_{4}^{2}\right)^{0.5}}{\mathrm{R}_{4}}\right) \frac{1}{2 \pi \mathrm{L}_{\mathrm{he}} \mathrm{k}_{\mathrm{PCM}, \mathrm{L}}}+\log \left(\frac{\mathrm{R}_{5}}{\left(\mathrm{f}\left(\mathrm{R}_{5}^{2}-\mathrm{R}_{4}^{2}\right)+\mathrm{R}_{4}^{2}\right)^{0.5}}\right) \frac{1}{2 \pi \mathrm{L}_{\mathrm{he}} \mathrm{k}_{\mathrm{PCM}, \mathrm{S}}}$

Total heat transfer rate $Q_{w}$, the total heat transferred to the water is assumed equal to the total useful heat $Q_{u}$ minus the heat transferred to the PCM $Q_{P C M, c}$ : 


\subsubsection{Discharging the PCM}

The heat transferred from water in the middle tube to the PCM is expressed as follows:

$\mathrm{Q}_{\mathrm{PCM}, \mathrm{d}}=\varepsilon_{\mathrm{d}} \mathrm{C}_{\min }\left(\mathrm{T}_{\mathrm{PCM}}-\mathrm{T}_{\mathrm{c}, \mathrm{in}}\right)$

With $\varepsilon_{d}$ the average effectiveness of the solidification process is expressed as follows

Total heat transfer rate $Q_{w}$, the total heat transferred to the cold water is assumed equal to the sum of the heat released from the PCM QPCM,d and the useful heat $Q_{u}$ :

$\mathrm{Q}_{\mathrm{w}}=\mathrm{Q}_{\mathrm{PCM}, \mathrm{d}}+\mathrm{Q}_{\mathrm{u}}$

\subsection{Definition of the system performance}

The energy efficiency of the system is characterized by two main parameters:

$\checkmark$ The overall thermal efficiency $\eta_{\mathrm{o}}$ of the PVT module, that is the sum of the electrical efficiency $\eta_{\mathrm{e}}$ and the thermal efficiency $\eta_{\text {th }}$ of the system.

$\eta_{\mathrm{o}}=\eta_{\mathrm{e}}+\eta_{\mathrm{th}}$

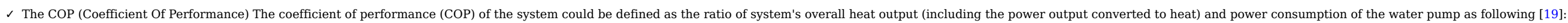
$\mathrm{COP}=\frac{\mathrm{Q}_{\mathrm{w}}+\mathrm{Q}_{\mathrm{e}} / 0.38}{\mathrm{P}_{\text {pump }}}$

The electricity consumption of the pump is expresses as follows:

$$
\mathrm{P}_{\text {pump }}=\frac{\mathrm{Q}_{\mathrm{v}} \rho_{\mathrm{w}} \mathrm{gH}}{\eta_{\text {pump }}}
$$

Where $\mathrm{Qv}$ is the water volume flow rate, $\eta_{\text {pump }}$ the efficiency of the pump and $\mathrm{H}$ the total height $\mathrm{H}$ expressed as following:

$H=f_{a n} \frac{L_{h e}}{D_{3}-D_{2}}\left(\frac{u_{w}^{2}}{2 g}\right)+\sum K\left(\frac{u_{w}^{2}}{2 g}\right)$

Where $\mathrm{f}_{\mathrm{an}}$ is the friction factor for an annular tube given in Annex 3 and $\Sigma \mathrm{K}$ is the sum of loss coefficient for the four 180 returned bend, inlet and outlet fittings [25].

\subsection{Presentation of the algorithm of the integrated model of the PVT system}

The global model is resolved by ensuring the heat balance at the micro-channel evaporator and at the PCM heat exchanger. The algorithm is summarized in Fig. 6 . 


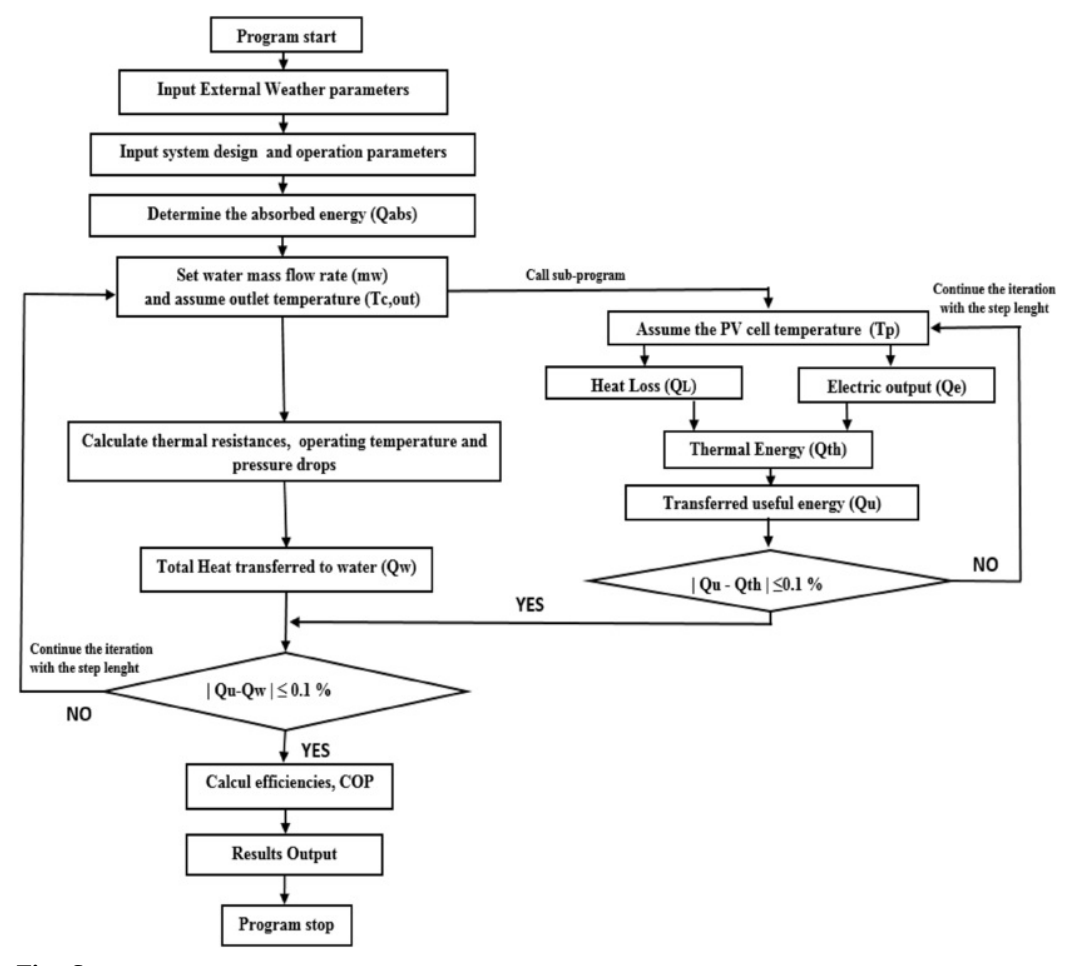

Fig. 6 PV/LHP thermal performance model. alt-text: Fig. 6

The algorithm is illustrated as follows:

(i) Input external weather variables, system design and operating parameters;

(ii) Calculate the Absorbed heat equation (A.1) (Annex 1)

(iii) Set the cold water mass flow $\mathrm{m}_{\mathrm{w}}$ rate and the water inlet temperature $T_{\mathrm{c}, \text { int }}$

(iv) Assume the outlet temperature of the water $\mathrm{T}_{\mathrm{c}, \text { out }}$.

(v) Calculate the total heat transfer rate $\mathrm{Q}_{\mathrm{w}}$ Equation (25) (Charge process) or 27 (Discharge process).

(vi) Assume the cell temperature $\mathrm{Tp}$, and commence the following analysis:

A. Heat balance of the glazing cover could be analysed using equations A.2 to A.12, which gives the heat loss, QL;

B. Heat balance of the PV cells gives of the converted solar electricity, $Q_{e}$ and heat, $Q_{t h}$; (A.10 and A.12).

C. Heat transfer from the PV cells to the PCM heat exchanger could be analysed by Equations (1)-(17), which gives the useful heat gain, $Q_{u}$;

D. If $\left(\mathrm{Q}_{\mathrm{th}}-\mathrm{Q}_{\mathrm{u}}\right) / \mathrm{Q}_{\mathrm{th}}>0.1 \%$ (error allowance), then increase tp by $0.1{ }^{\circ} \mathrm{C}$ and return to step (vi) for re-calculation;

E. If $\left(\mathrm{Q}_{\mathrm{th}}-\mathrm{Q}_{\mathrm{u}}\right) / \mathrm{Q}_{\mathrm{th}}<-0.1 \%$ (error allowance), then decrease tp by $0.1^{\circ} \mathrm{C}$ and return to step (vi) for re-calculation;

F. If $-0.1 \% \leq\left(Q_{\text {th }}-Q_{\mathrm{u}}\right) / Q_{\text {th }} \leq 0.1 \%$, the system achieves heat balance; 
(vii) If $\left(\mathrm{Q}_{\mathrm{u}}-\mathrm{Q}_{\mathrm{w}}\right) / \mathrm{Q}_{\mathrm{u}}>0.1 \%$ (error allowance), then increase $\mathrm{T}_{\mathrm{c}, \text { out }}$ by $0.1{ }^{\circ} \mathrm{C}$ and return to step (iii) for re-calculation;

(viii) If $\left(\mathrm{Q}_{\mathrm{u}}-\mathrm{Q}_{\mathrm{w}}\right) / \mathrm{Q}_{\mathrm{u}}<-0.1 \%$ (error allowance), then decrease $0.1{ }^{\circ} \mathrm{C}$ and return to step (iii) for re-calculation;

(ix) If $-0.1 \% \leq\left(Q_{u}-Q_{w}\right) / Q_{u} \leq 0.1 \%$, the system achieves heat balance;

(x) Calculate the module's energetic efficiencies and the overall performance coefficient of $\operatorname{COP}_{\mathrm{PV} / \mathrm{T}}$ using Equations (28)-(31) and the program stops.

\subsection{Parametric study on the energy efficiency od the new PVT system}

In this part, the established computer model has been used to study the influence of the following parameters on the energy performance of the system

$\checkmark$ the weather conditions (external parameters: solar radiation, ambient temperature, wind velocity)

$\checkmark$ the system configuration (internal parameters: cover number, packing factor, number of heat pipes),

$\checkmark$ the working fluid characteristics (water inlet temperature, water mass flow rate).

\subsubsection{Influence of the solar radiation}

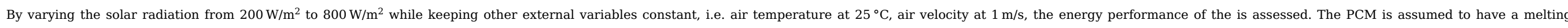

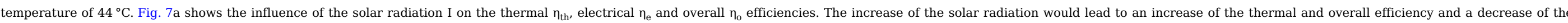

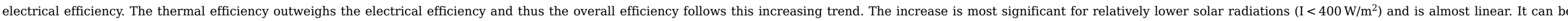

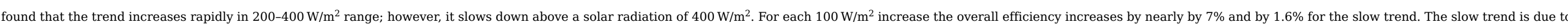

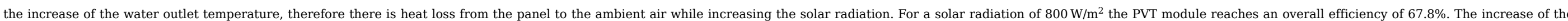

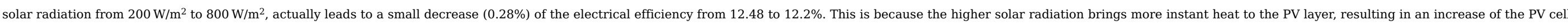
temperature as shown in Fig. $7 \mathrm{~b}$ and the decrease of the electrical efficiency. For a solar radiation of $800 \mathrm{~W} / \mathrm{m}^{2}$ the PVT module reaches an overall efficiency of $67.8 \%$.

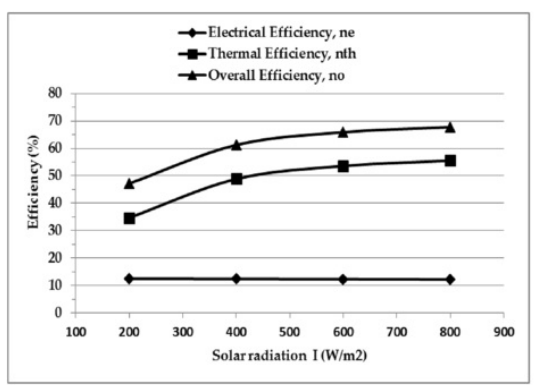

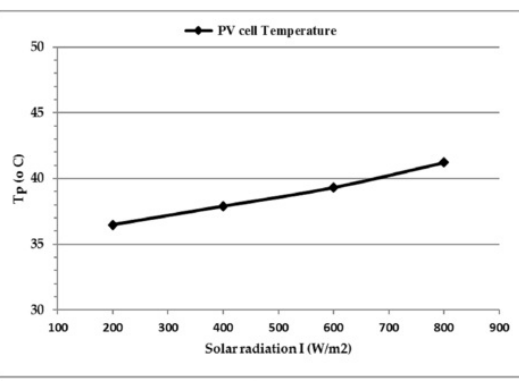

Fig. 7 Influence of solar radiation on: a) the thermal, electrical, overall efficiencies, b) PV cell temperature. alt-text: Fig. 7

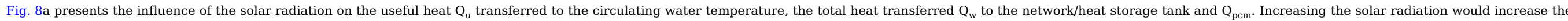

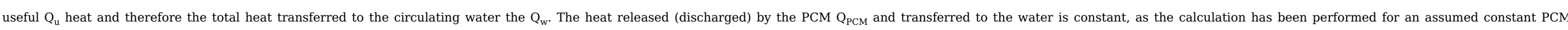

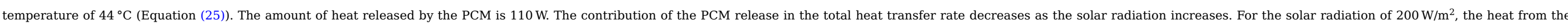

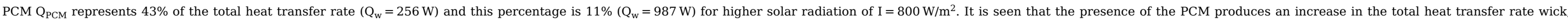

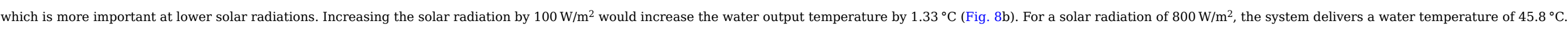



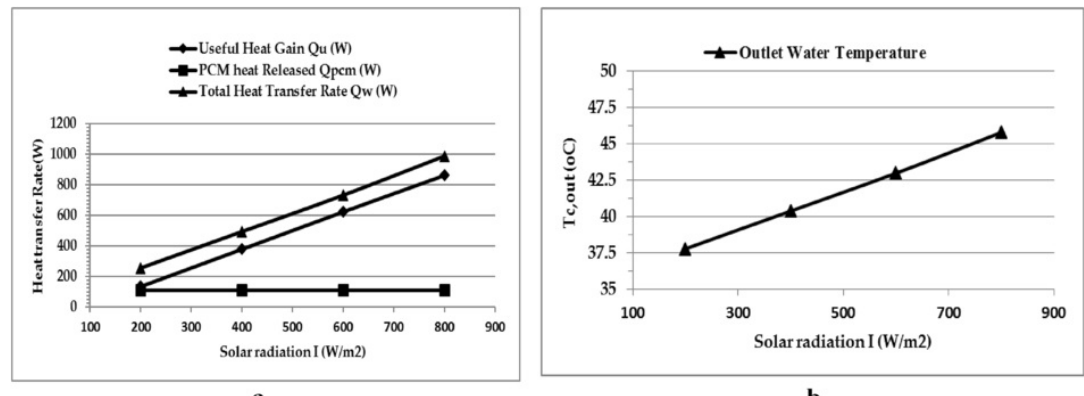

Fig. 8 Influence of solar radiation on a) the heat outputs and b) the water outlet temperature.

alt-text: Fig. 8

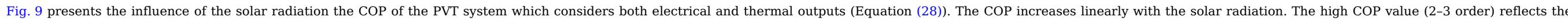

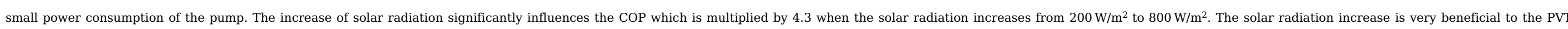
system.

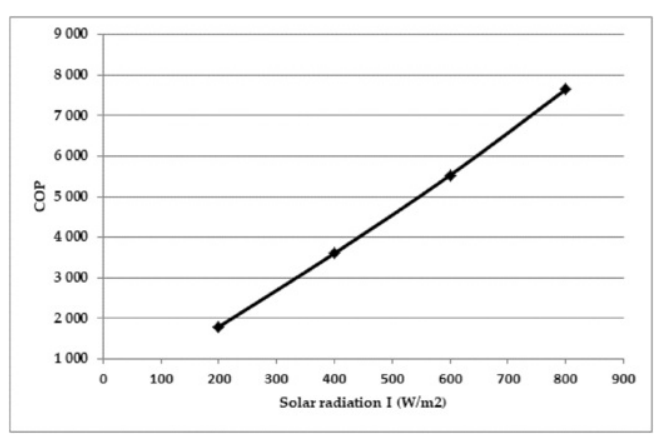

Fig. 9 Influence of solar radiation on the COP.

\section{alt-text: Fig. 9}

\subsubsection{Influence of the ambient temperature}

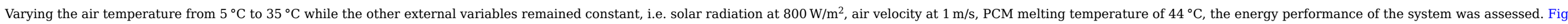

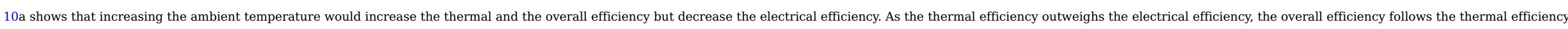

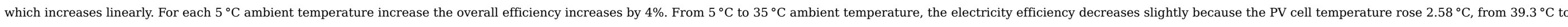

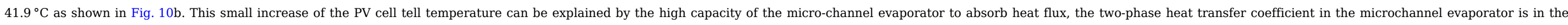
order of $4 \times 10^{3} \mathrm{~W} / \mathrm{m}^{2} / \mathrm{K}$ and by the heat loss decrease when increasing the ambient temperature. 


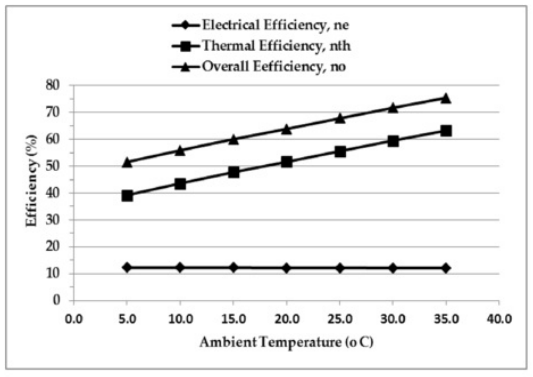

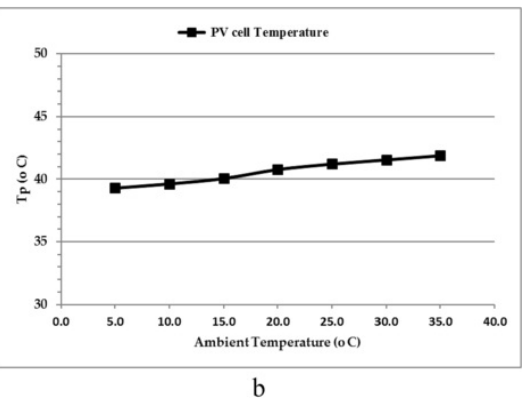

Fig. 10 Influence of the ambient air temperature on: a) the thermal, electrical, and overall efficiencies, b) PV cell temperature.

alt-text: Fig. 10

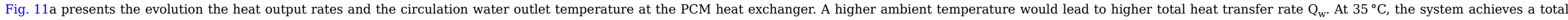

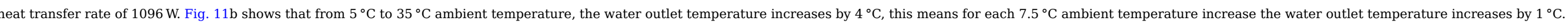

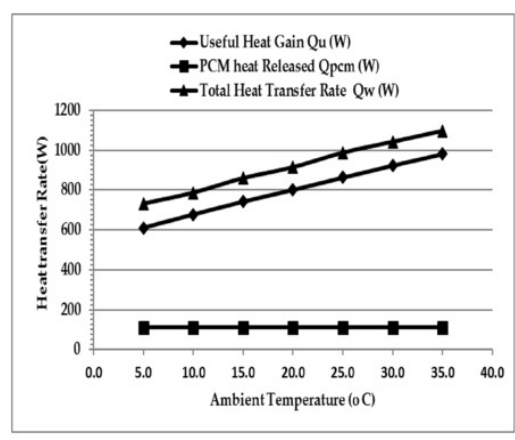

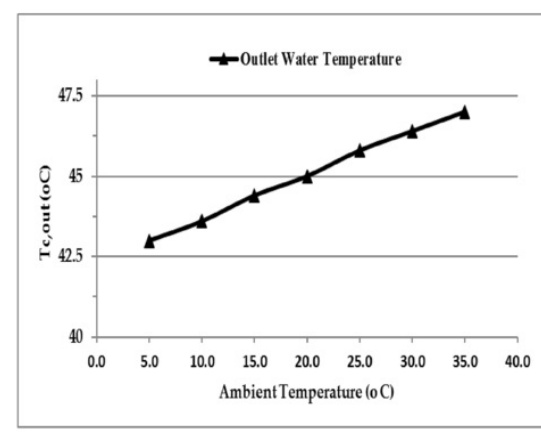

Fig. 11 Influence of the ambient temperature on a) the heat outputs and b) the water outlet temperature. alt-text: Fig. 11

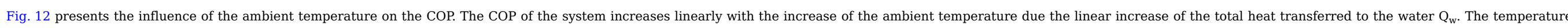

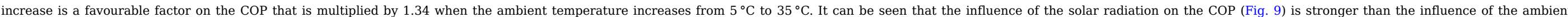
temperature (Fig. 12)

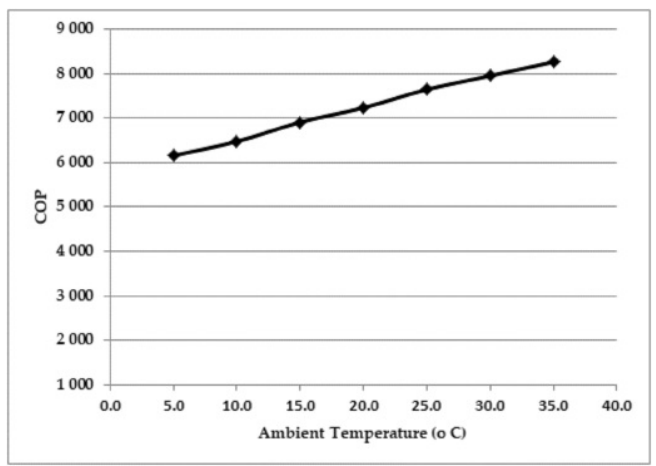




\section{alt-text: Fig. 12}

\subsubsection{Influence of the wind velocity}

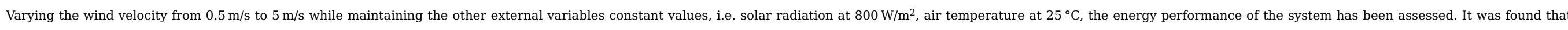

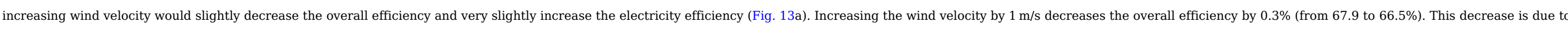

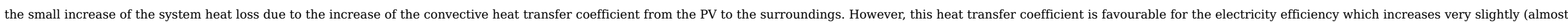

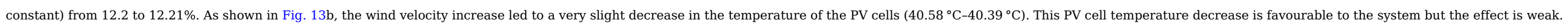

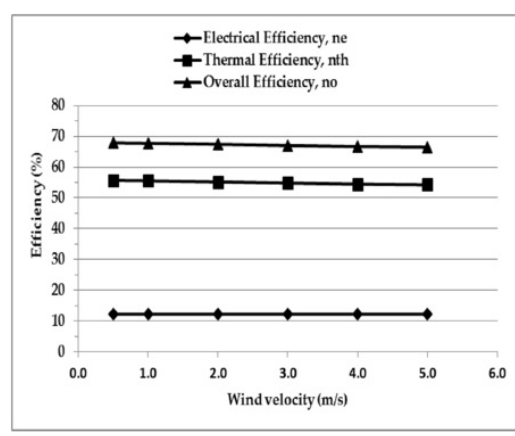

a

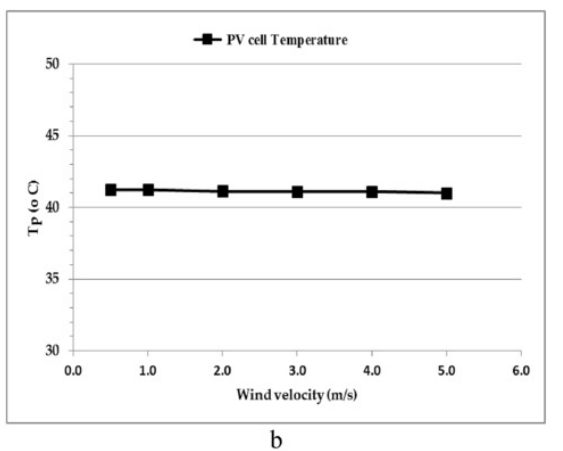

Fig. 13 Influence of the wind velocity on the a) the thermal, electrical, and overall efficiencies, b) PV cell temperature.

alt-text: Fig. 13

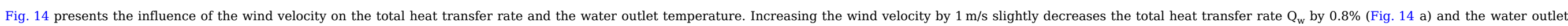
temperature $\mathrm{T}_{\mathrm{C}, \text { out }}$ by $0.08^{\circ} \mathrm{C}$ (Fig. $14 \mathrm{~b}$ ).

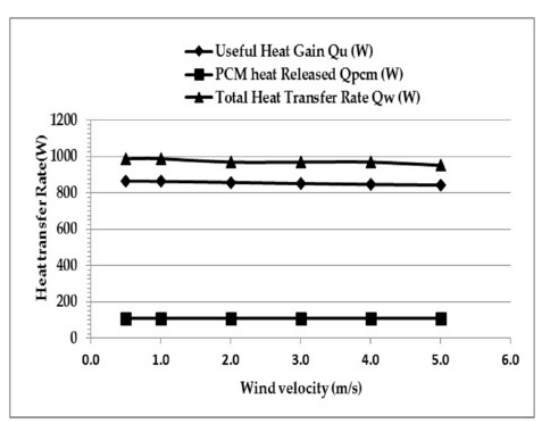

a

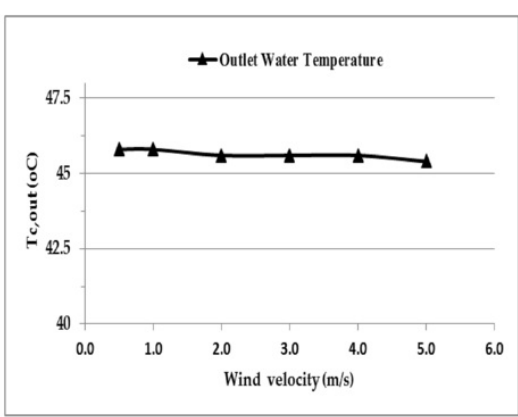

Fig. 14 Influence of wind velocity on: a) the heat outputs and b) the water outlet temperature. alt-text: Fig. 14

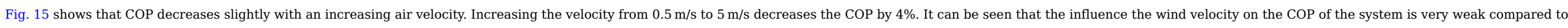
the influences of the solar radiation (Fig. 9) and the ambient temperature (Fig. 12). 


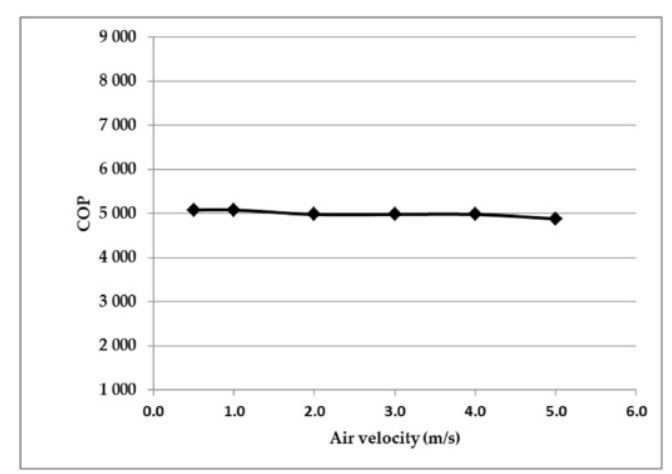

Fig. 15 Influence of wind velocity on the COP.

alt-text: Fig. 15

\subsubsection{Influence of number of cover}

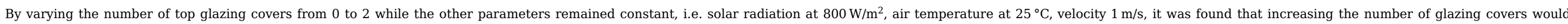

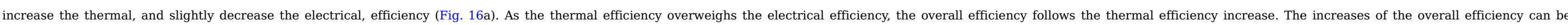

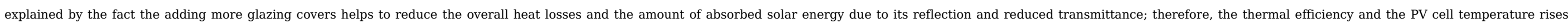
slightly from 39.2 to $40.9^{\circ} \mathrm{C}$ (Fig. 16b), and then the electrical efficiency falls slightly (12.19\%-12.17\%). The increase of the cover number is favourable for thermal efficiency and unfavourable for electrical efficiency

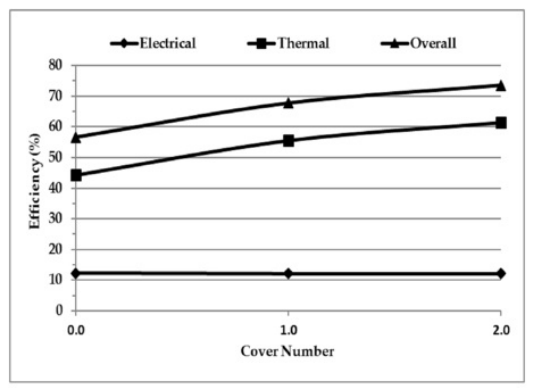

a

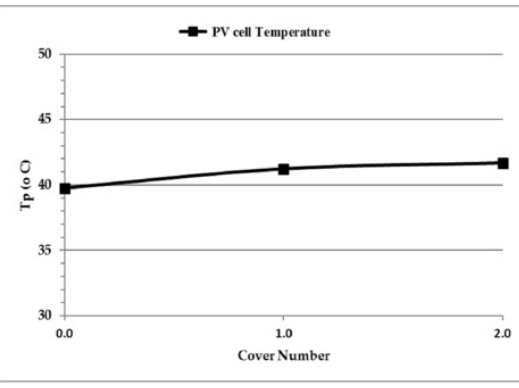

b

Fig. 16 Influence of the cover number on the efficiency. alt-text: Fig. 16

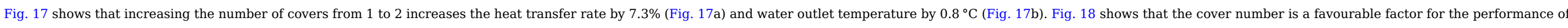

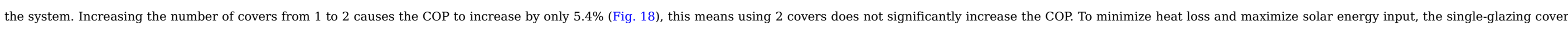
was considered to be the most appropriate option. 

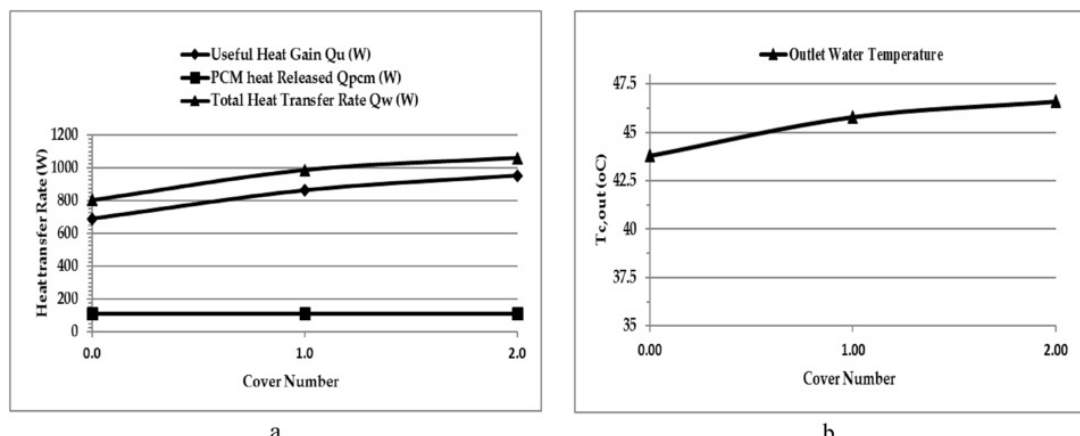

Fig. 17 Influence of the cover number on heat transfer rates and the outlet water temperature.

alt-text: Fig. 17

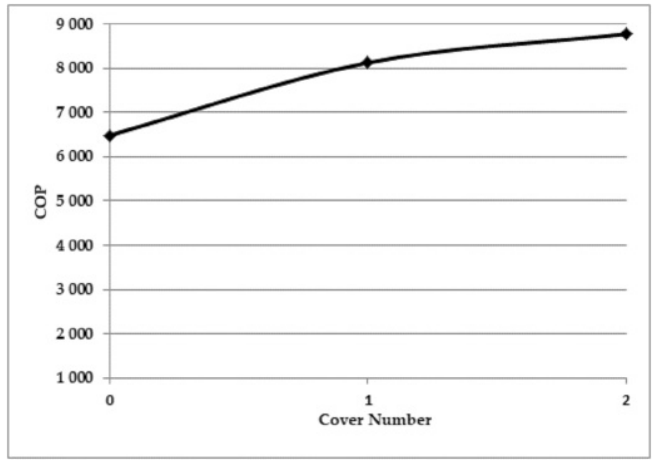

Fig. 18 Influence of the cover on the COP.

\section{alt-text: Fig. 18}

\subsubsection{Influence of the packing factor}

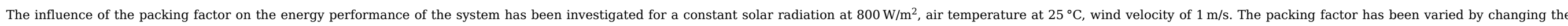

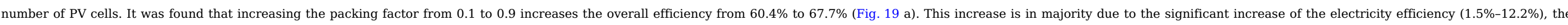

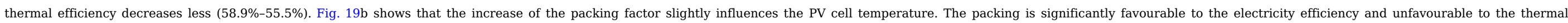
efficiency.
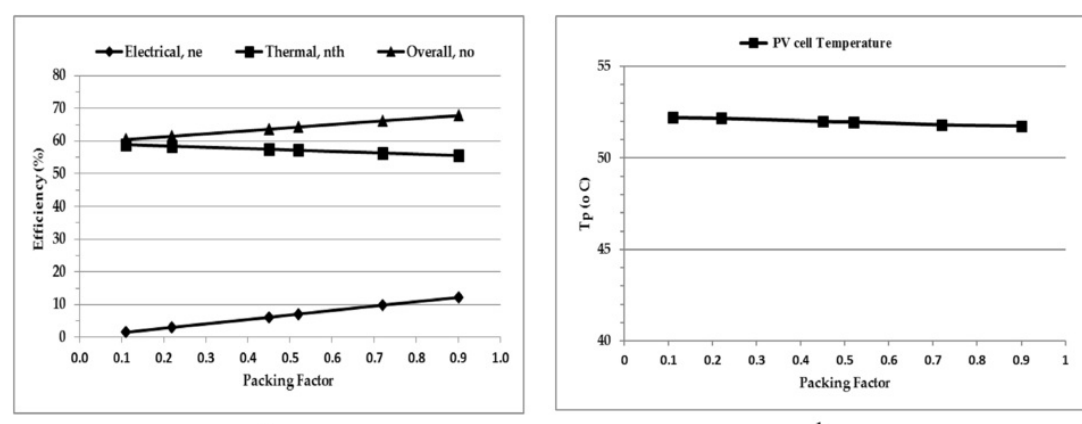


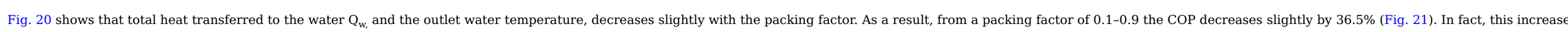
of the COP is due to the increase of the electrical output that compensates the small decrease of the total heat output. Finally, it was found that higher packing factor is beneficial for the overall system performance.
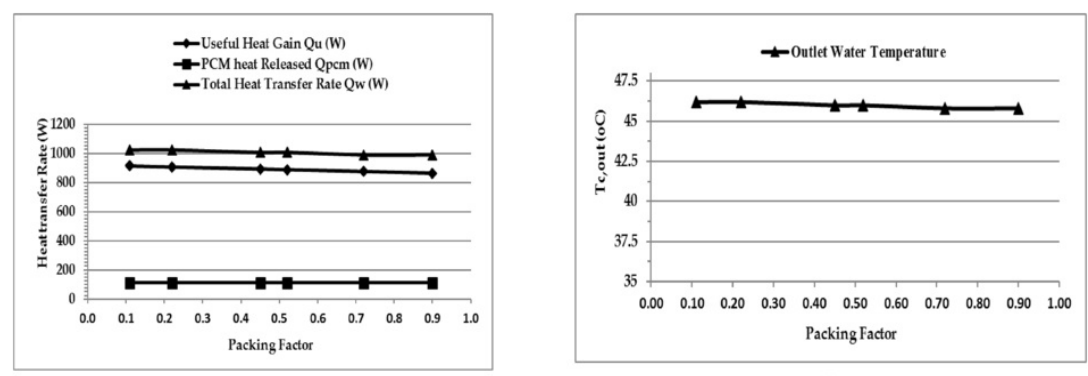

a

b

Fig. 20 Influence of the packing factor on heat transfer rates and the outlet water.

alt-text: Fig. 20

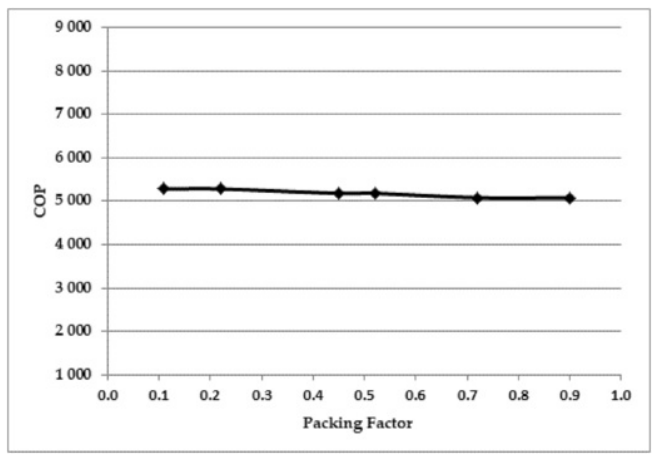

Fig. 21 Influence of the packing factor on the COP.

alt-text: Fig. 21

\subsubsection{Influence of number of heat pipe}

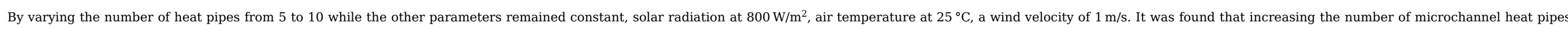

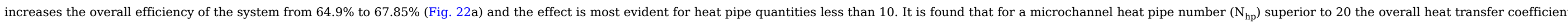

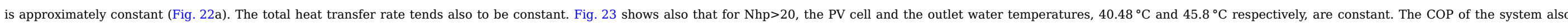
follows this behaviour (Fig. 24) and is constant for a $\mathrm{N}_{\mathrm{hp}}$ superior to 20. This means that 20 microchannel heat pipes represent an optimal microchannel number. 


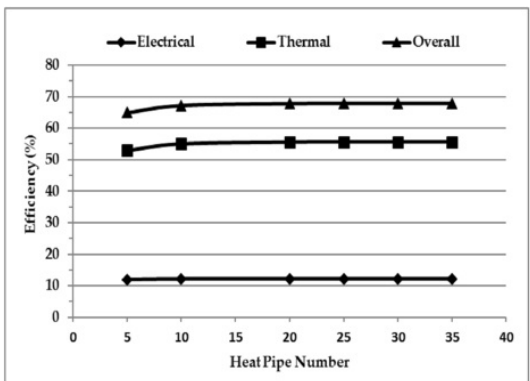

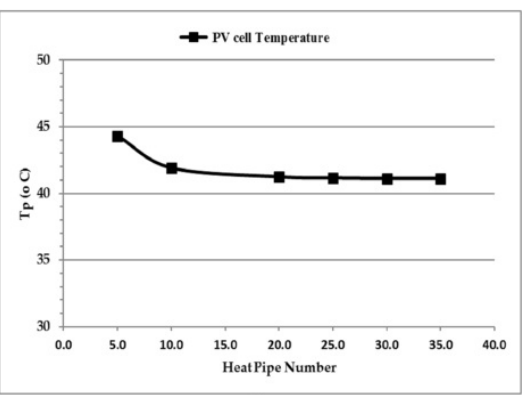

b

Fig. 22 Influence of the microchannel heat pipe number on the efficiency.

alt-text: Fig. 22
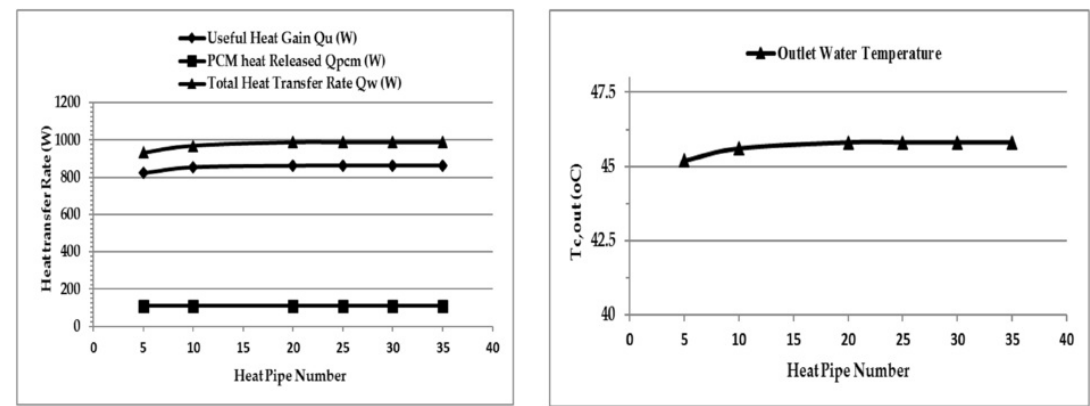

b

Fig. 23 Influence of microchannel the heat pipe number on the PV cell temperature and the outlet water temperature, alt-text: Fig. 23

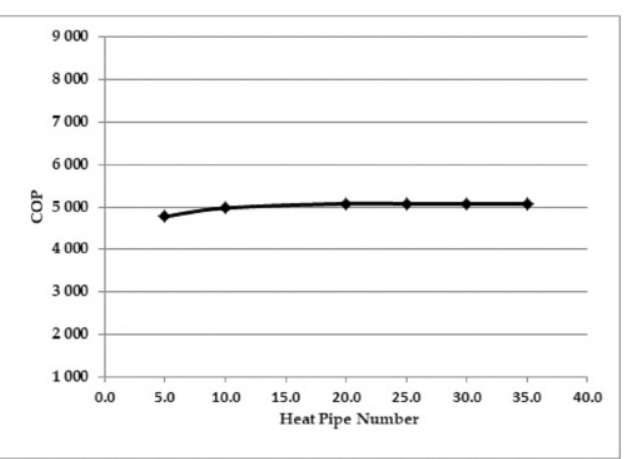

Fig. 24 Influence of microchannel heat pipe number on the COP.

\section{alt-text: Fig. 24}

\subsubsection{Influence of water inlet temperature}

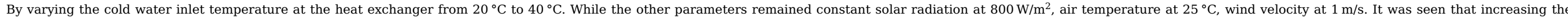

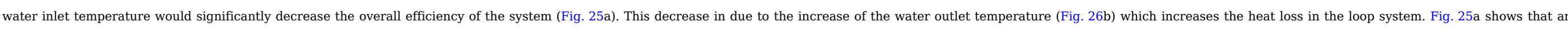




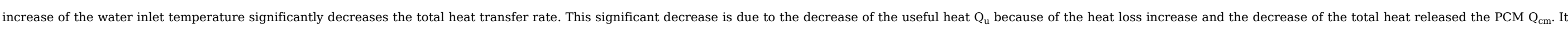
can be seen that for a water inlet temperature near $38^{\circ} \mathrm{C}$ the useful heat $\mathrm{Q}_{\mathrm{u}}$ is superior to the total heat transfer rate $\mathrm{Q}_{\mathrm{w}}$ (Fig. 25b). This means there is excess heat is charged in the PCM.
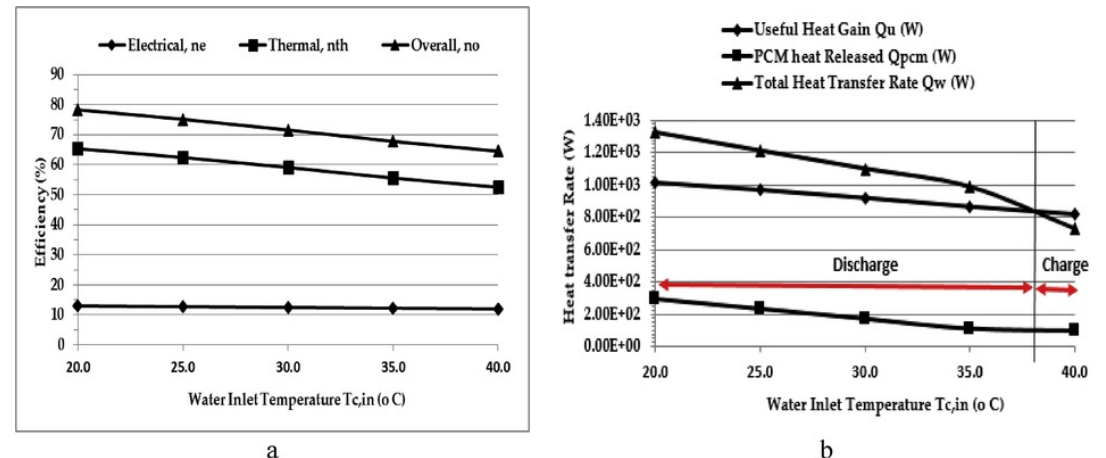

b

Fig. 25 Influence of the water inlet temperature on the efficiency.

alt-text: Fig. 25

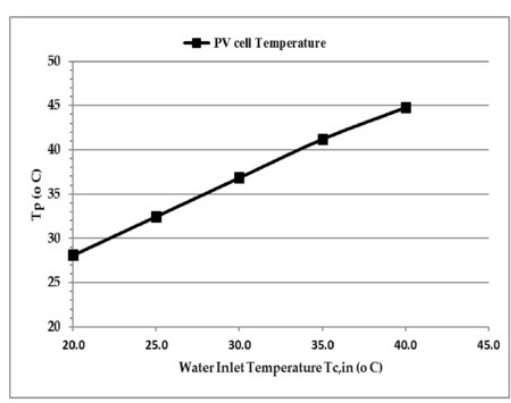

a

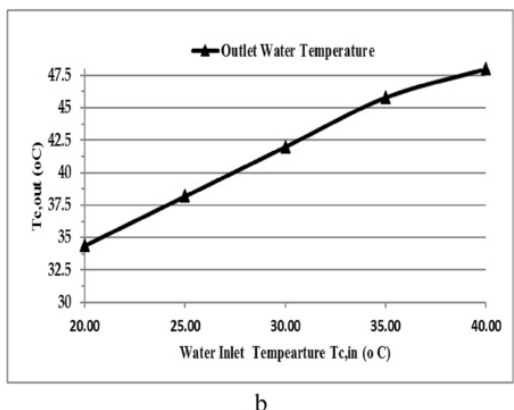

Fig. 26 Influence of the water inlet temperature on heat transfer rates and the outlet water. alt-text: Fig. 26

Fig. 27 shows that the COP evolution presents a maximum value where the heat excess is beginning to be charged in the PCM and the COP falls.

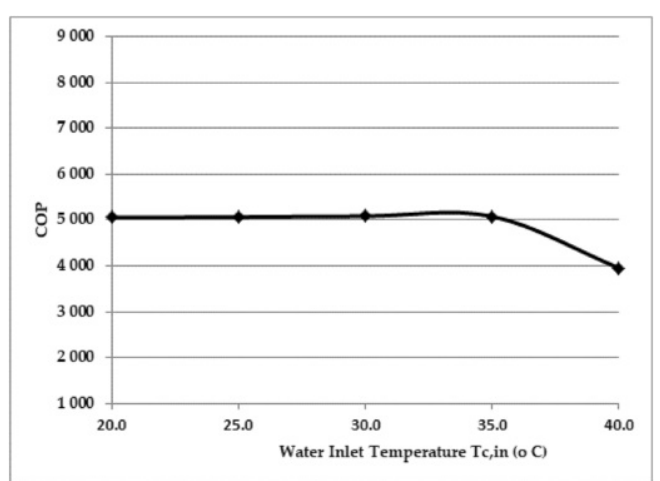

Fig. 27 Influence of the water inlet temperature on the COP.

alt-text: Fig. 27 


\subsubsection{Influence of the water mass flow}

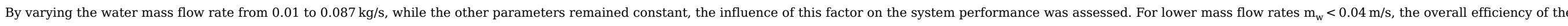

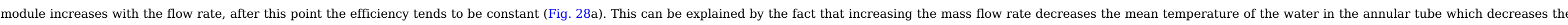

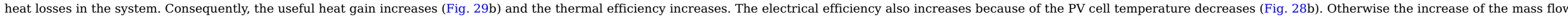

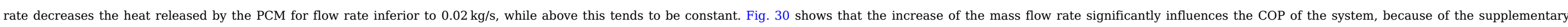
electricity consumption of the system. It is seen that the flow rate of $0.0125 \mathrm{~kg} / \mathrm{s}$ would be an optimal value for high COP and high heat output simultaneously.

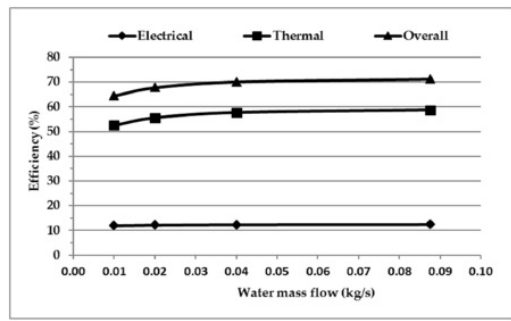

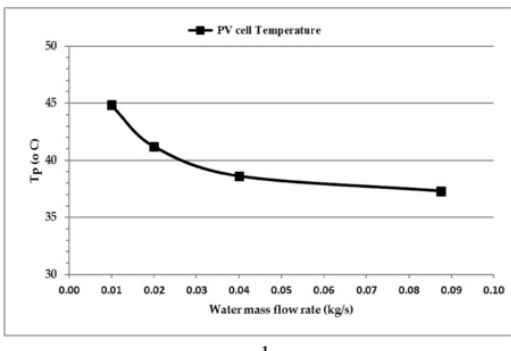

Fig. 28 Influence of the water mass flow rate on heat transfer rates and the outlet water.

alt-text: Fig. 28

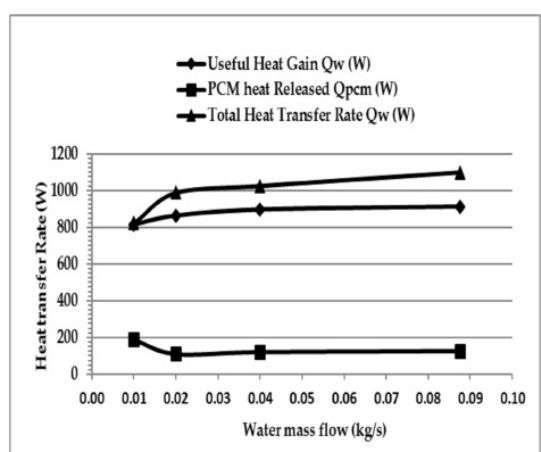

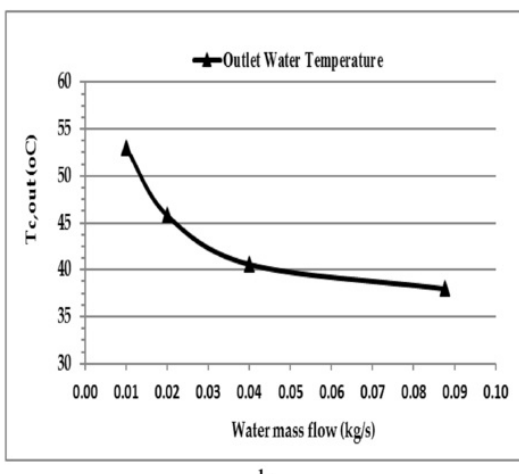

b

Fig. 29 Influence of the water mass flow rate on the efficiency.

alt-text: Fig. 29 


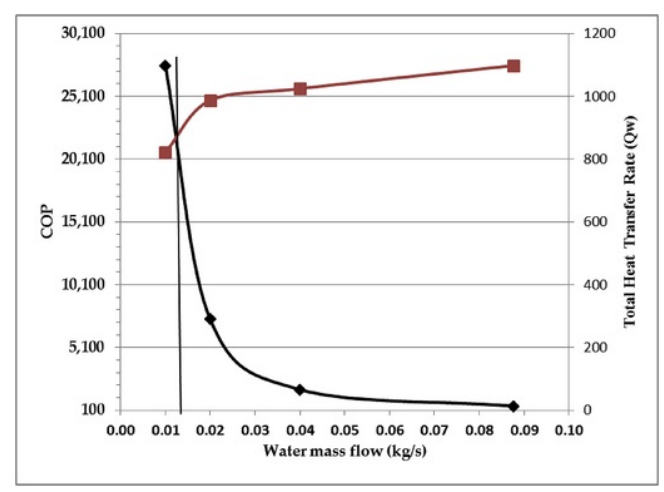

Fig. 30 Influence of the water mass flow rate on the COP.

\section{alt-text: Fig. 30}

\subsection{Comparision of the novel system with a conventional system}

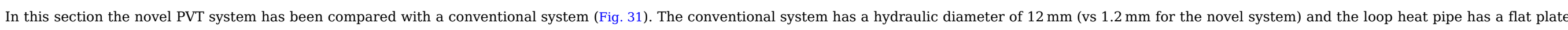

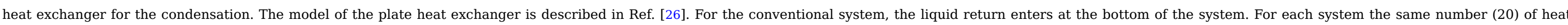

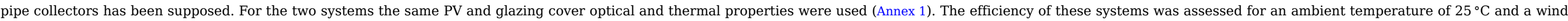
velocity of $1 \mathrm{~m} / \mathrm{s}$

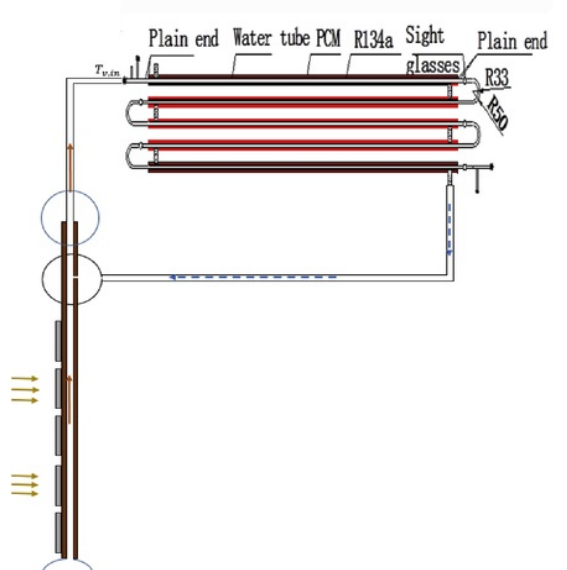

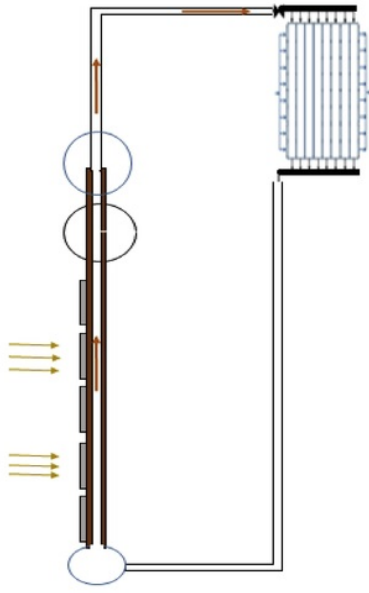

Fig. 31 Comparison between, a) the novel PVT system b) the conventional PVT system.

alt-text: Fig. 31

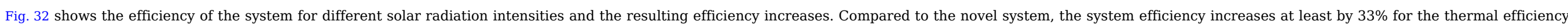

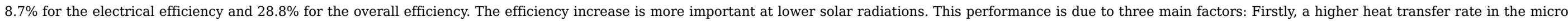

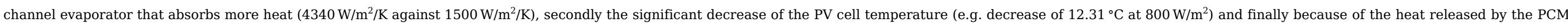
heat exchanger. 

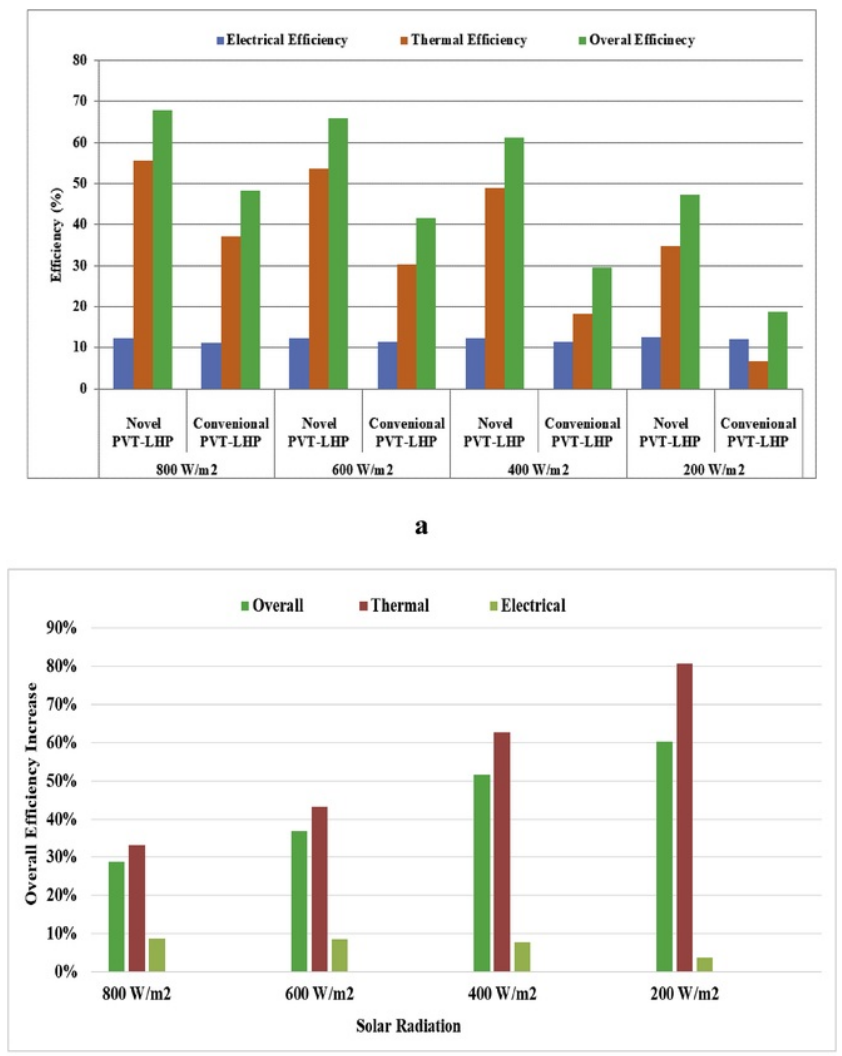

b

Fig. 32 Comparison between the new PVT system and the conventional PVT system a) evolution of thermal, electrical, overall efficiencies b) overall efficiency increase. alt-text: Fig. 32

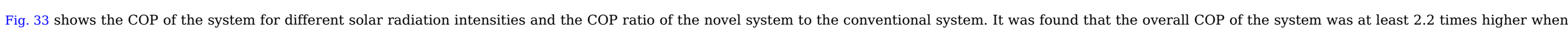
compared to the conventional system. This higher COP is due to the higher heat output of the novel system and the lower power consumption of the water pump ( $0.18 \mathrm{~W}$ against $0.12 \mathrm{~W}$ ). 


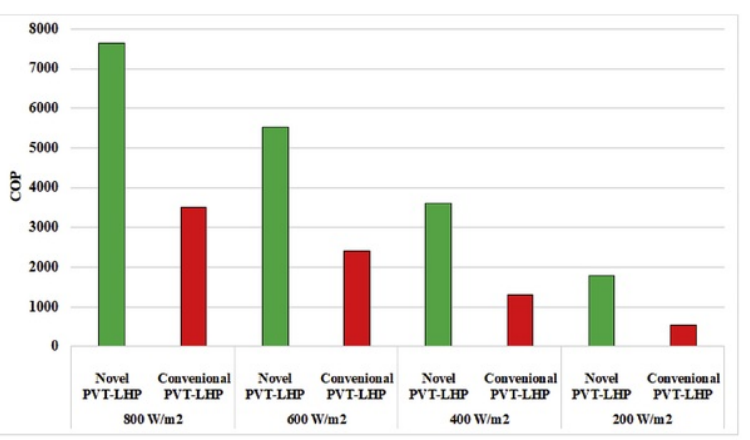

a

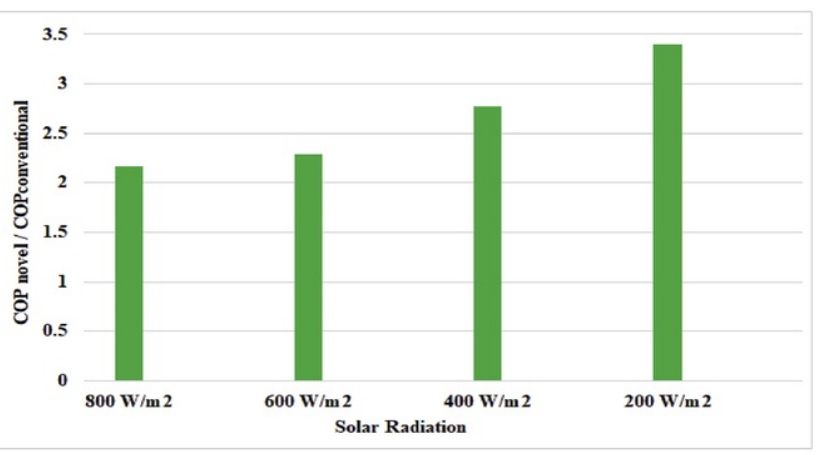

b

Fig. 33 Comparison between the new PVT system and the conventional PVT system a) evolution of the COP and b) the ratio of COP novel to COP conventional.

\section{alt-text: Fig. 33}

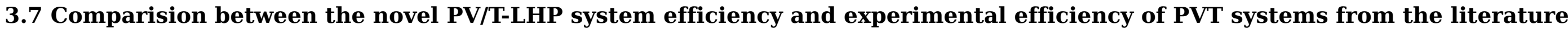

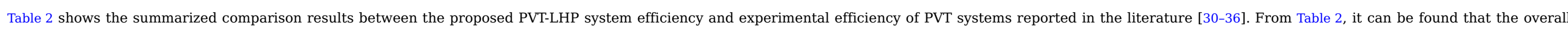

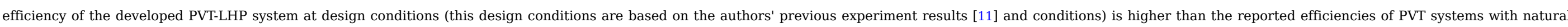

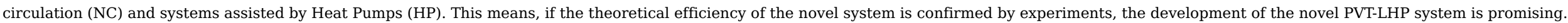

Table 2 Comparison of the novel system efficiency and the experimental efficiency of PVT systems in the literature.

alt-text: Table 2

\section{Solar radiation $\left(\mathrm{W} / \mathrm{m}^{2}\right)$}

800

800

800

Daily average

Summer (value not indicated)
Electrical Efficiency (\%)

\begin{tabular}{c}
12.2 \\
\hline 7.9 \\
\hline 11.3 \\
9.13
\end{tabular}

Thermal efficiency (\%)

55.6

54

54

$$
\text { Overall efficiency (\%) }
$$

$$
67.85 \text { (NC) }
$$

61.9 (with HP assistance)

65.3 (with HP assistance)

48.37 (HP assistance)

36.97 (NC)

$62(\mathrm{NC})$
Reference

Present study

[30] (Fig. $12 \mathrm{Q}_{\mathrm{m}}=0,03 \mathrm{~kg} / \mathrm{s}$ )

[31]

[32]

[33]

$11+51$




\section{Conclusion}

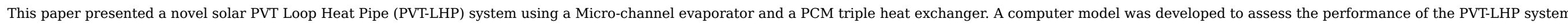

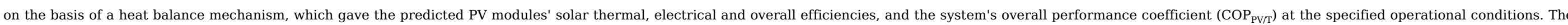

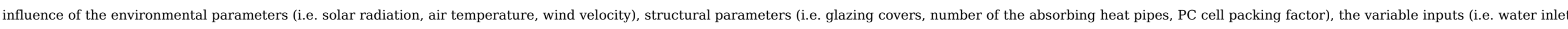
temperature, mass flow rate) on the energy performance of the system was investigated individually. The novel PVT-LHP has been compared with a conventional Solar PVT-LHP system. It was found that:

(1) Increasing the solar radiation led to an increase in thermal efficiency but a decrease in the electrical efficiency, resulting in an increase the system's overall performance coefficient ( $\left.\mathrm{CO}_{\mathrm{PV} / \mathrm{T}}\right)$;

(2) Increasing the ambient air temperature led to an increase in the thermal efficiency, a decrease in the electrical efficiency and an increase in the system's overall performance coefficient (COP ${ }_{\mathrm{PV} / \mathrm{I}}$ )

(3) Increasing the wind speed led to a slight decrease in the thermal efficiency, slight increase in the electrical efficiency and slight decrease in the system's overall performance coefficient ( $\left.\mathrm{COP}_{\mathrm{PV} / \mathrm{T}}\right)$;

(4) Increasing the number of the glazing covers led to an increase in the module's thermal efficiency but a decrease in the module's electrical efficiency and in the system's overall performance coefficient ( $\left.\mathrm{COP}_{\mathrm{PV} / \mathrm{T}}\right)$

(5) Increasing the packing factor led to a decrease in the module's thermal efficiency but an increase in the module's electrical efficiency and in the system's overall performance coefficient (COP ${ }_{\mathrm{PV} / \mathrm{T}}$ )

(6) Increasing the number of the heat absorbing pipes led to an increase in the fin's efficiency and in the system's overall performance coefficient.

(7) Increasing the cold water inlet temperature led to a decrease in the module's thermal efficiency, the module's electrical efficiency, and the system's overall performance coefficient (COP $\mathrm{PV} / \mathrm{T})$.

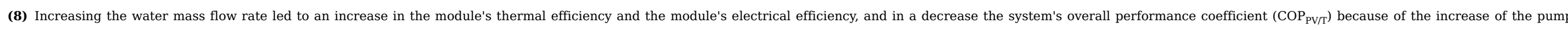
electricity consumption. The results show that a flow rate of $0.0125 \mathrm{~kg} / \mathrm{s}$ would be an optimal flow for a high Heat output and high COP simultaneously.

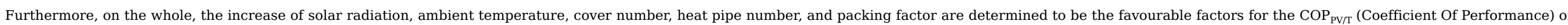

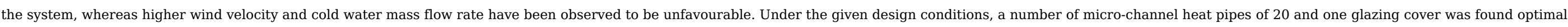

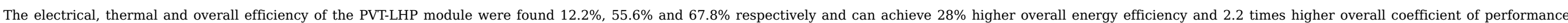
$\mathrm{COP}_{\mathrm{PV} / \mathrm{T}}$ compared to the conventional system. The model developed in this study can be used to design and optimize the energy performance of a novel PVT-LHP system.

\section{Acknowledgments}

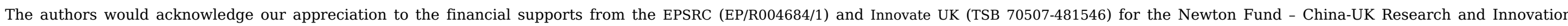

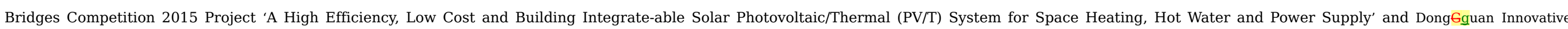
Research Team Program (No. 2014607101008).

\section{Annex 1 characteristics of different PVT layers}

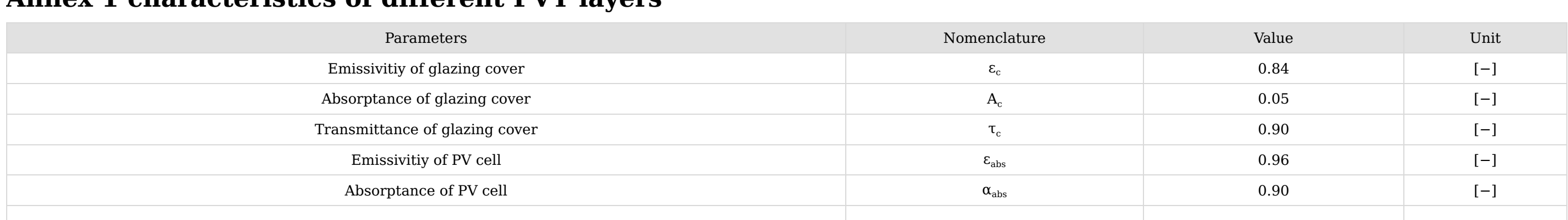




\begin{tabular}{|c|c|c|c|}
\hline Thickness of PV Cell & $\delta_{\mathrm{abs}}$ & 0.0003 & $\mathrm{~m}$ \\
\hline Thermal conductivity of PV cell & $\lambda_{\text {abs }}$ & 148 & $\mathrm{~W} / \mathrm{m} / \mathrm{K}$ \\
\hline Reference efficiency of PV Cell & $\eta_{\mathrm{rc}}$ & 0.18 & {$[-]$} \\
\hline Temperature coefficient of PV cell & $\beta_{\text {abs }}$ & 0.0045 & $1 /{ }^{\circ} \mathrm{C}$ \\
\hline Reference temperature of PV cell & $\operatorname{trc}$ & 25 & ${ }^{\circ} \mathrm{C}$ \\
\hline Number of PV cell & $\mathrm{N}_{\mathrm{pv}}$ & 72 & {$[-]$} \\
\hline Area of single PV cell & $\mathrm{A}_{\mathrm{pv}}$ & $0.156 * 0.156$ & $\mathrm{~m}^{2}$ \\
\hline Thickness of EVA grease & $\delta_{\text {eva }}$ & 0.0005 & $\mathrm{~m}$ \\
\hline Thermal conductivity of EVA grease & $\lambda_{\text {eva }}$ & 0.35 & $\mathrm{~W} / \mathrm{m} / \mathrm{K}$ \\
\hline Thickness of electrical insulation & $\delta_{\text {ei }}$ & 0.002 & $\mathrm{~m}$ \\
\hline Thermal conductivity of electrical insulation & $\lambda_{\mathrm{ei}}$ & 144 & $\mathrm{~W} / \mathrm{m} \cdot \mathrm{K}$ \\
\hline Absorptance of blacken electrical insulation & $\mathrm{A}_{\mathrm{ei}}$ & 0.8 & {$[-]$} \\
\hline Thickness of fin sheet & of & 0.005 & {$[-]$} \\
\hline Thermal conductivity of fin sheet & $\lambda_{\mathrm{f}}$ & 203 & {$[-]$} \\
\hline
\end{tabular}

\section{Annex 2 heat transfer from outside to the PV surface [19].}

The solar energy received by the PV module is expressed as follows:

$\mathrm{Q}_{\mathrm{abs}}=\tau_{\mathrm{c}}^{\mathrm{N}_{\mathrm{C}}} \tau_{\mathrm{g}, \mathrm{pv}}\left[\alpha_{\mathrm{p}} \beta_{\mathrm{p}}+\alpha_{\mathrm{b}}\left(1-\beta_{\mathrm{p}}\right)\right] \mathrm{A}_{m} I$

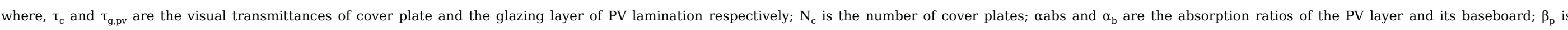

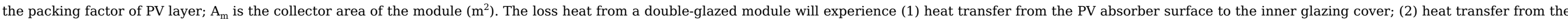
inner cover to the outer cover; and (3) heat transfer from the outer glazing cover to the ambient air. As shown in the following figure, the three forms of heat transfer are laid in a series and achieve a balance.

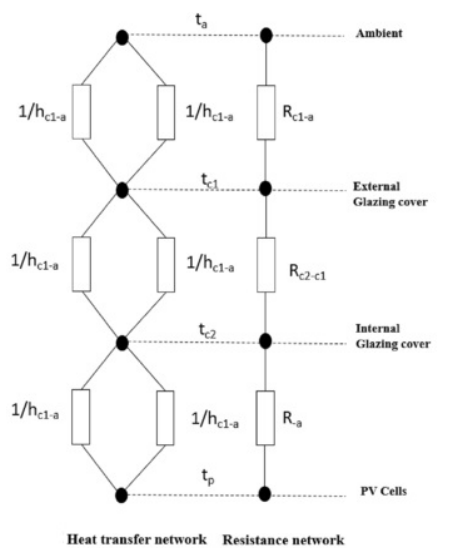

Thermal network of heat loss for a typical double-cover module alt-text: Image 2

Therefore, the total heat loss is written as: 
Where, $Q_{L}$ and $U_{L}$ are the total heat loss $(W)$ and the heat loss coefficient $\left(W / m^{2}-K\right)$ respectively; $T_{p}$ and $T_{a}$ are the average temperatures of PV layer and the ambient air (K). Where the $U_{L}$ is the overall heat transfer coefficient and could be written:

$\mathrm{U}_{\mathrm{L}}=\left(\frac{1}{\mathrm{~h}_{\mathrm{c}, \mathrm{p}-\mathrm{c} 2}+\mathrm{h}_{\mathrm{R}, \mathrm{p}-\mathrm{c} 2}}+\frac{1}{\mathrm{~h}_{\mathrm{c}, \mathrm{c} 2-\mathrm{cl} 1}+\mathrm{h}_{\mathrm{R}, \mathrm{c} 2 \mathrm{cl}}}+\frac{1}{\mathrm{~h}_{\mathrm{c}, \mathrm{cl} 1-\mathrm{a}}+\mathrm{h}_{\mathrm{R}, \mathrm{c} 1-\mathrm{a}}}\right)^{-1}$

where, $h_{c, p-c 2}, h_{c, c 2-c 1}$ and $h_{c, c 1-a}$ are respectively the convective heat transfer coefficients (W/ $\mathrm{m}^{2}-\mathrm{K}$ ) of PV layer (p) to inner cover surface (c2), inner cover surface (c2) to external cover surface (c1) and external cover surface (c1) to ambient air (a); $\mathrm{h}_{\mathrm{R}, \mathrm{p} \cdot \mathrm{c} 2}, \mathrm{~h}_{\mathrm{R}, \mathrm{c} 2 \cdot \mathrm{cl}}$ and $\mathrm{h}_{\mathrm{R}, \mathrm{c} 1 \mathrm{a}}$ are the radiative heat transfer coefficients ( $\left.\mathrm{W} / \mathrm{m}^{2}-\mathrm{K}\right)$ of PV layer (p) to inner cover surface (c2), inner cover surface (c2) to external cover surface (c1) and external cover surface (c1) to ambient air (a) respectively.

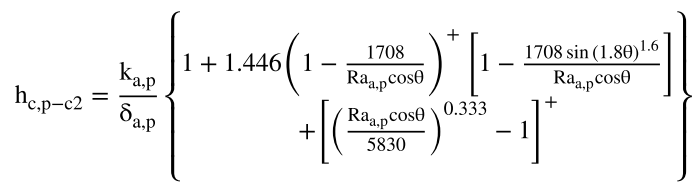

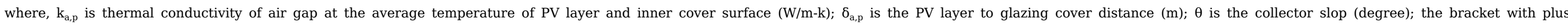
means zero and positive values only; $\mathrm{Ra}_{\mathrm{a}, \mathrm{p}}$ is the Rayleigh number of the air gap at PV layer and inner cover surface, given by:

$\mathrm{Ra}_{\mathrm{a}, \mathrm{p}}=\frac{\mathrm{g}\left(\mathrm{T}_{\mathrm{P}}-\mathrm{T}_{\mathrm{C} 2}\right) \delta_{\mathrm{a}, \mathrm{p}}^{3}}{\mathrm{v}_{\mathrm{a}, \mathrm{p}}^{2} \mathrm{~T}_{\mathrm{a}, \mathrm{m}}} \underset{\mathrm{a}, \mathrm{p}}{\mathrm{Pr}}$

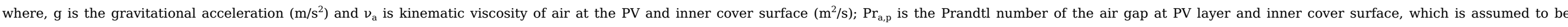
independent of temperature and taken equal to $0.7 ; \mathrm{T}_{\mathrm{a}, \mathrm{m}}$ is the average air temperature of PV layer and inner cover surface which is

$\mathrm{T}_{\mathrm{a}, \mathrm{m}}=\frac{\left(\mathrm{T}_{\mathrm{P}}+\mathrm{T}_{\mathrm{c} 2}\right)}{2}$

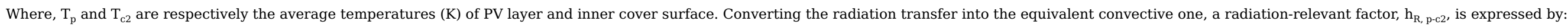

$\mathrm{h}_{\mathrm{R}, \mathrm{p}-\mathrm{c} 2}=\frac{\sigma\left(\mathrm{T}_{\mathrm{p}}+\mathrm{T}_{\mathrm{c} 2}\right)\left(\mathrm{T}_{\mathrm{p}}^{2}+\mathrm{T}_{\mathrm{c} 2}^{2}\right)}{\left(\frac{1}{\varepsilon_{\mathrm{p}}}\right)+\left(\frac{1}{\varepsilon_{\mathrm{c} 2}}\right)-1}$

Where, $\mathrm{T}_{\mathrm{c} 1}$ is the average temperature of external cover surface $(\mathrm{K}) ; \varepsilon_{\mathrm{p}}$ and $\varepsilon_{\mathrm{c} 2}$ are emissivity of the PV layer and inner cover surface; $\sigma$ is the Stefan $-\mathrm{Boltzmann}$ constant $\left(5.6679 \times 10-8 \mathrm{~W} / \mathrm{m}^{2}-\mathrm{K} 4\right)$.

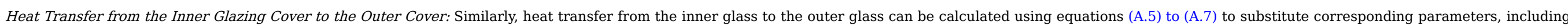
temperature, air properties, and emissivity.

Heat Transfer from the Cover's Outer Surface to the Surrounding Air: For a surface exposed to the outside wind, the convective coefficient could be calculated using the Klein equation expressed as follows:

$\mathrm{h}_{\mathrm{c}, \mathrm{c} 1-\mathrm{a}}=\frac{8.6 \mathrm{~V}^{0.6}}{\mathrm{~L}^{0.6}}$

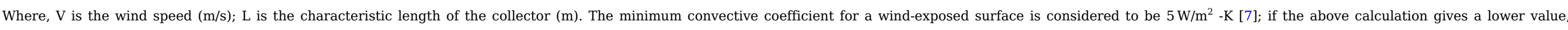
this should be replaced by the minimum value since the temperature of the sky has little influence on the calculation result, it is usually represented by the air temperature, thus

$\mathrm{h}_{\mathrm{r}, \mathrm{cl}-\mathrm{a}}=\varepsilon_{\mathrm{cl}} \sigma\left(\mathrm{T}_{\mathrm{cl}}+\mathrm{T}_{\mathrm{a}}\right)\left(\mathrm{T}_{\mathrm{cl}}^{2}+\mathrm{T}_{\mathrm{a}}^{2}\right)$

The PV cells' electrical efficiency is adversely proportional to their surface temperature and this dependency can be written as:

$\eta_{\mathrm{e}}=\eta_{\mathrm{rc}}\left(1-\beta_{\mathrm{PV}}\left(\mathrm{T}_{\mathrm{p}}-\mathrm{T}_{\mathrm{rc}}\right)\right)$ 
The module's solar electrical efficiency could be calculated through $\eta_{\mathrm{e}}=\frac{\mathrm{Q}_{\mathrm{e}}}{\mathrm{IA}_{\mathrm{m}}}$

Under the steady-state condition, the rate of useful heat delivered by the module equals the rate of the absorbed energy minus the overall heat loss and converted electricity, expressed as $\mathrm{Q}_{\mathrm{th}}=\mathrm{Q}_{\mathrm{abs}}-\mathrm{Q}_{\mathrm{L}}-\mathrm{Q}_{\mathrm{e}}$

This part of the heat will eventually be converted into the heat received by the water and stored, which is denoted by $Q_{u}$. In this case, the module's thermal efficiency can be defined by: $\eta_{\mathrm{th}}=\frac{\mathrm{Q}_{\mathrm{th}}}{\mathrm{A}_{\mathrm{m}} \mathrm{I}}$

\section{(A2.13)}

\section{Annex 3}

\section{A- The two phase heat transfer coefficient}

The two-phase heat transfer Kandiklar correlation [27] has been used and is expressed as follows:

$$
\begin{aligned}
& \text { For ReLO }>100 \mathrm{~h}_{\mathrm{TP}}=\text { larger of }\left\{\begin{array}{l}
\mathrm{h}_{\mathrm{TP}, \mathrm{NBD}} \\
\mathrm{h}_{\mathrm{TP}, \mathrm{CBD}}
\end{array}\right. \\
& \mathrm{h}_{\mathrm{TP}, \mathrm{NBD}}=0.6683 \mathrm{Co}^{-0.2}(1-\mathrm{x})^{0.8} \mathrm{~h}_{\mathrm{LO}}+1058.0 \mathrm{Bo}^{0.7}(1-\mathrm{x})^{0.8} \mathrm{~F}_{\mathrm{F} 1} \mathrm{~h}_{\mathrm{LO}} \\
& \mathrm{h}_{\mathrm{TP}, \mathrm{NBD}}=1.136 \mathrm{Co}^{-0.9}(1-\mathrm{x})^{0.8} \mathrm{~h}_{\mathrm{LO}}+667.2 \mathrm{Bo}^{0.7}(1-\mathrm{x})^{0.8} \mathrm{~F}_{\mathrm{Fl}} \mathrm{h}_{\mathrm{LO}} \\
& \text { Where: } \\
& \mathrm{Co}=[(1-\mathrm{x}) / \mathrm{x}]^{0.8}\left(\frac{\rho_{\mathrm{v}}}{\rho_{\mathrm{L}}}\right)^{0.5} \\
& \text { Bo }=\frac{\mathrm{q}}{\mathrm{Gh}_{\mathrm{fg}}} \\
& \text { For } 10^{4} \leq \operatorname{Re}_{\mathrm{LO}} \leq 510^{6} \mathrm{~h}_{\mathrm{LO}}=\frac{\operatorname{Re}_{\mathrm{LO}} \operatorname{Pr}_{\mathrm{L}}\left(\frac{\mathrm{f}}{2}\right)\left(\frac{\mathrm{k}_{\mathrm{L}}}{\mathrm{D}}\right)}{1+12.7\left(\operatorname{Pr}_{\mathrm{L}}^{2 / 3}-1\right)(\mathrm{f} / 2)^{0.5}} \\
& \text { For } 3000 \leq \mathrm{Re}_{\mathrm{LO}} 10^{4} \mathrm{~h}_{\mathrm{LO}}=\frac{\left(\operatorname{Re}_{\mathrm{LO}}-1000\right) \operatorname{Pr}_{\mathrm{L}}\left(\frac{\mathrm{f}}{2}\right)\left(\frac{\mathrm{k}_{\mathrm{L}}}{\mathrm{D}}\right)}{1+12.7\left(\operatorname{Pr}_{\mathrm{L}}^{2 / 3}-1\right)(\mathrm{f} / 2)^{0.5}} \\
& \text { For } 100 \leq \operatorname{Re}_{\mathrm{LO}} \leq 1600 \mathrm{~h}_{\mathrm{LO}}=\frac{N u_{L O} k}{D_{h}}
\end{aligned}
$$

In the transition region between Reynolds numbers of 1600 and 3000, a linear interpolation is suggested for $\mathrm{h}_{\mathrm{LO}}$.

For Reynolds numbers below and equal to 100 ( $R e \leq 100)$, the nucleate boiling mechanism governs, and the following Kandiklar correlation is proposed: ForRe $_{\mathrm{LO}} \leq 100$

$\mathrm{h}_{\mathrm{TP}}=\mathrm{h}_{\mathrm{TP}, \mathrm{NBD}}=0.6683 \mathrm{Co}^{-0.2}(1-\mathrm{x})^{0.8} \mathrm{~h}_{\mathrm{LO}}+1058.0 \mathrm{Bo}^{0.7}(1-\mathrm{x})^{0.8} \mathrm{~F}_{\mathrm{Fl}} \mathrm{h}_{\mathrm{LO}}$

For R-134a the recommended value of $\mathrm{F}_{\mathrm{Fl}}$ is 1.63 . 


\section{B- The condensation heat transfer coefficient [28].}

For $\operatorname{Rev}<35000 \mathrm{~h}_{\text {cond }}=0.555\left[\frac{\rho_{\mathrm{g}} \mathrm{g}\left(\rho_{1}-\rho_{\mathrm{v}}\right) \mathrm{k}_{1}^{3} \mathrm{~h}_{\mathrm{fg}}}{\mu_{\mathrm{l}}\left(\mathrm{T}_{\text {sat }}-\mathrm{T}_{\mathrm{w}}\right) \mathrm{D}}\right]^{1 / 4}$

For $\mathrm{R}_{\mathrm{ev}}>35000$

$$
\mathrm{h}_{\mathrm{cond}}=\frac{\mathrm{k}_{1}}{\mathrm{D}} 0.23 \operatorname{Re}_{\mathrm{D}}^{0.8 .8}{ }_{1}^{0.4}\left[1+\frac{2.22}{\mathrm{X}_{\mathrm{tt}}^{0.89}}\right] \text {, }
$$

$\mathrm{Re}_{\mathrm{D}}=4 \cdot(1-\mathrm{x}) /(\pi \mathrm{D} \mu \mathrm{m})$

$\mathrm{X}_{\mathrm{tt}}=\left(\frac{1-\mathrm{x}}{\mathrm{x}}\right)^{0.9}\left(\frac{\rho_{\mathrm{v}}}{\rho_{\mathrm{l}}}\right)^{0.5}\left(\frac{\mu_{1}}{\mu_{\mathrm{v}}}\right)^{0.1}$

\section{C- The fins efficiency in the microchannel [28].}

$\varepsilon_{\text {of }}=1-N_{f} A_{f}\left(1-\varepsilon_{f}\right) / A_{t f} ; \varepsilon_{f}=\tanh \left(m_{f} L_{c f}\right) / m_{f} L_{c f}$

$\mathrm{m}_{\mathrm{f}}=\left(2 \times \mathrm{h}_{\mathrm{tp}} \times\left(\mathrm{L}_{\mathrm{e}}+\mathrm{t}_{\mathrm{f}}\right) /\left(\mathrm{K}_{\mathrm{hp}} \mathrm{L}_{\mathrm{e}} \mathrm{t}_{\mathrm{f}}\right)\right)^{0.5}$

$L_{c f}=b+\frac{\delta_{f}}{2} ; A_{t f}=N_{f} A_{f}+A_{b} A_{b}=L_{h p} L_{e} A_{f}=L_{e} \delta_{f}$

\section{C- Heat transfer in the Annulus [29].}

The flow in the annular is characterize by the following Nusselt number and friction factors:

For laminar flow:

$\mathrm{Re}<2200 \quad \mathrm{f}=24 \mathrm{Re}^{-1} \quad \mathrm{Nu}=9.33$

$\operatorname{Re}>4000 \mathrm{f}=0.0885 \mathrm{Re}^{-0.263} \mathrm{Nu}=0.02 \mathrm{Re}^{0.733} \stackrel{1 / 3}{\mathrm{Pr}}$

(A3.11)

(A3.12)

For $2200 \leq \operatorname{Re} \leq 4000$ an interpolation has been performed.

$\mathrm{h}_{\mathrm{w}}=\frac{\mathrm{Nu} \mathrm{k}_{\mathrm{w}}}{\mathrm{D}_{45}}$

Where $D_{45}$ is the hydraulic diameter based on wetted perimeter, $\mathrm{m}$

$\mathrm{D}_{45}=\frac{\pi\left(\mathrm{D}_{5}^{2}-\mathrm{D}_{4}^{2}\right)}{\pi \mathrm{D}_{5}+\pi \mathrm{D}_{4}}$

Reynolds number $\mathrm{Re}_{W}$ can be calculated by:

$\operatorname{Re}_{\mathrm{w}}=\frac{\rho_{\mathrm{cf}} \mathrm{u}_{1} \mathrm{D}_{45}}{\mu_{\mathrm{cf}}}$

The Prandtl number $\operatorname{Pr}_{\mathrm{w}}$ is calculated using

$\underset{\mathrm{w}}{\operatorname{Pr}}=\frac{\mu_{\mathrm{cf}} \mathrm{c}_{\mathrm{pcf}}}{\mathrm{k}_{\mathrm{w}}}$ 
Where $\mu_{\mathrm{cf}}, \mathrm{c}_{\mathrm{pcf}}, \rho_{\mathrm{cf}}, \mathrm{k}_{\mathrm{w}}$ are the relevant mean dynamic viscosity $(\mathrm{kg} / \mathrm{m}-\mathrm{s})$, specific heat, density, thermal conductivity of the water.

\section{References}

[1] Technology roadmap-solar photovoltaic energy, 2010, International Energy Agency http://www.iea-pvps.org, [accessed 11.04.11].

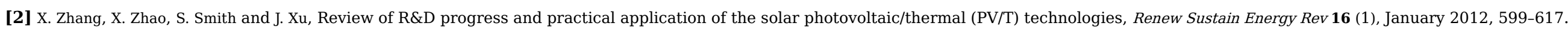

[3] H.A. Zondag, Flat-plate PV-Thermal collectors and systems A review, Renew Sustain Energy Rev 12, 2008, 891-959.

[4] C. Lamnatou and D. Chemisana, Photovoltaic/thermal (PVT) systems: a review with emphasis on environmental issues, Renew Energy 105, $2017,270-287$.

[5] T.T. Chow, A review on photovoltaic/thermal hybrid solar technology, Appl Energy 87 (2), 2010, 365-379.

[6] Y. Tripanagnostopoulos, M. Souliotis, R. Battisti and A. Corrado, Application aspects of hybrid PV/T solar systems, In: ISES Solar world congress, Göteborg, 2003.

[7] Evidence Gathering, Low carbon heating technologies - hybrid solar photovoltaic thermal panels, 2016, Department of Business, Energy, and industrial Strategy, Repoer BRE, Delta-ee.

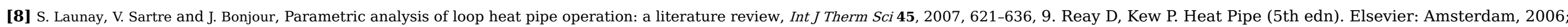
48-52, 93-96, 122 and 234-236.10.

[9] M. Bertela and J. Prakash, Transport of thermal energy by a simple two-phase loop, Int J Energy Res 12, 1988, 679-698.

[10] Z. Wang and W. Yang, A review on loop heat pipe for use in solar water heating, Energy Build 79, 2014, 143-154.

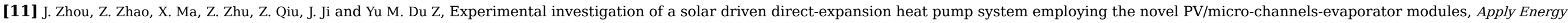
178, 2016, 484-495.

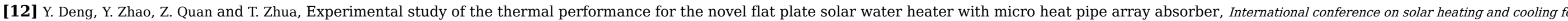
buildings and industry, SHC 2014, energy procedia vol. 70, 2015, 41-48.

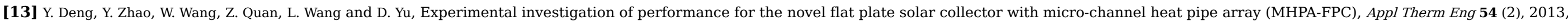
440-449.

[14] T. Zhu, Y. Diao, Y. Zhao and F. Li, Thermal performance of a new CPC solar air collector with flat micro-heat pipe arrays, Appl Therm Eng 98, 2016, 1201-1213.

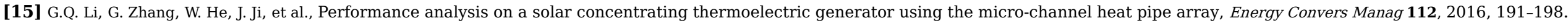

[16] G.Q. Li, W. Feng, Y. Jin, X. Chen and J. Ji, Discussion on the solar concentrating thermoelectric generation using micro-channel heat pipe array, Heat Mass Tran 53 (11), 2017 , $3249-3325$.

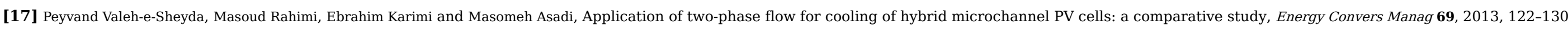

[18] M. Kuroda, J. Chang, P. Gwin and R. Mongia, Development of aluminium-water heat pipes, In: 17th International heat pipe conference (17th IHPC) Kanpur, India, October 13-17, 2013.

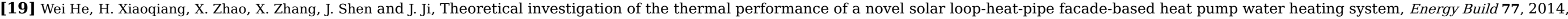
$180-191$.

[20] S.A. Kalogirou, Solar energy engineering: process and system, 2009, Elsevier Inc..

[21] H. Imura, H. Kusuda and S. Funatsu, Flooding velocity in a counter-current annular two-phase flow, Chem Eng Sci 32, 1977, pp79-87.

[22] P.K. Swamee and N. Swamee, Discharge equation of a circular sharp-crested orifice, J Hydraul Res 48 (1), 2010. 
[23] T. Diallo, M. Yu, J. Zhou and X. Zhao, Analytical investigation of the heat transfer limits of a novel solar loop-heat-pipe employing the mini-channel evaporator, Energies 11, 2018, 148, https://doi.org/10.3390/en11010148.

[24] N.H.S. Tay, M. Belusko and F. Bruno, An effectiveness-NTU technique for characterising tube-in-tank phase change thermal energy storage systems, Appl Energy 91, 2012 , 309-319.

[25] F.M. White, Fluid mechanics, seventh ed., 2011, McGraw-Hill; New York.

[26] X. Zhang, X. Zhao, J. Xu and X. Yu, Study of the heat transport capacity of a novel gravitational loop heat pipe, Int J Low Carbon Technol 8 (3), 2013 , $210-223$.

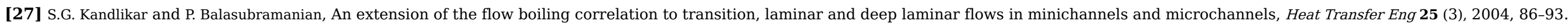

[28] F.P. Incropera, D.P. DeWitt, T.L. Bergman and A.S. Lavine, Fundamentals of heat and mass transfer, seventh ed., 2011, Wiley; Hoboken, NJ.

[29] R. Tiruselvam, W.M. Chin and Vijay R. Raghavan, Double tube heat exchanger with novel enhancement: part II-single phase convective heat transfer, Heat Mass Tran 48, 2012, 1451-1462, https://doi.org/10.1007/s00231-012-0986-x.

[30] S. Wu, Q. Zhang, X. Lan and F. Guo, A heat pipe photovoltaic/thermal (PV/T) hybrid system and its performance Evaluation, Energy Build 43, $2011,3558-3567$.

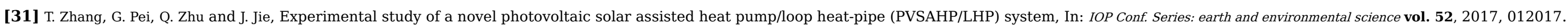

[32] X. Zhang, Investigation of a novel solar photovoltaic/loop-heat-pipe heat pump system, Thesis dissertationFebruary 2014, University of Hull.

[33] L. Lu, X. Wang, S. Wang and X. Liu, A new concept of hybrid photovoltaic thermal (PVT) collector with natural circulation, Heat Mass Tran 53, $2017,2331-2339$.

[34] T.T. Chow, J. Ji and W. He, Photovoltaic-thermal collector system for domestic application, J Sol Energy Eng 129 (2), 2007, $205-209$.

[35] W. He, T.T. Chow, J. Ji, J.P. Lu, G. Pei and L.S. Chan, Hybrid photovoltaic and thermal solar-collector designed for natural circulation of water, Appl Energy 83 (3), 2006 , 199-210.

[36] J. Ji, J.P. Lu, T.T. Chow, W. He and G. Pei, A sensitivity study of a hybrid photovoltaic/thermal water-heating system with natural circulation, Appl Energy 84 (2), 2007 , $222-237$.

\section{Graphical abstract}

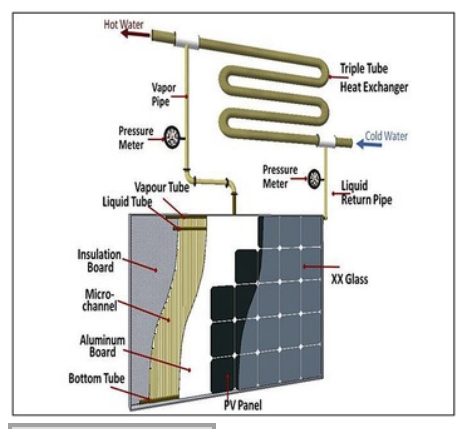

alt-text: Image 1

\section{Highlights}

- A novel PVT-LHP system is developed and modelled. 
- The system has $28 \%$ higher overall efficiency compared to a conventional system.

- The novel PVT-LHP has 2.2 times higher COP compared to a conventional system.

\section{Queries and Answers}

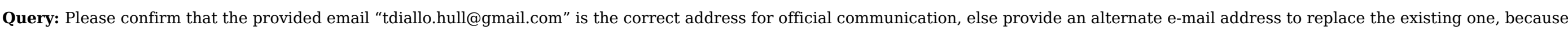
private e-mail addresses should not be used in articles as the address for communication.

Answer: please to use my new professionnal address that is: thierno.diallo@cstb.fr

Query: Have we correctly interpreted the following funding source(s) and country names you cited in your article: Innovate UK, United Kingdom; EPSRC, United Kingdom? Answer: Yes

Query: To maintain sequential order, equations((A2.7a), (A3.9a), (A3.13a), (A3.13b), (A3.13c)) have been renumbered. Please check, and correct if necessary. Answer: Please replace A2.7a by A2.8 then A2.8 becomes A2.9 and son on until A2.13 thant becomes A2.14. ok for others.

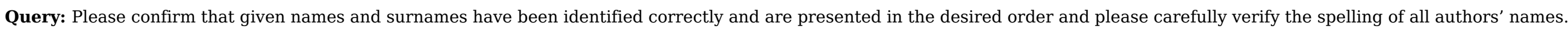
Answer: Yes

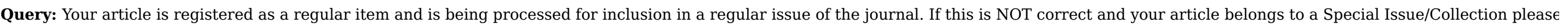
contact s.venkiteswaran@elsevier.com immediately prior to returning your corrections.

Answer: Yes 